$$
\begin{aligned}
& \text { UNIVERSIDADE DE SÃO PAULO } \\
& \text { INSTITUTO DE GEOCIÊNCIAS }
\end{aligned}
$$

\title{
NUMERICAL MODEL OF ALLUVIAL TERRACE AND VALLEY EVOLUTION APPLIED TO THE QUATERNARY OF CENTRAL AMAZONIA
}

Ariel Henrique do Prado

Orientador: Renato Paes de Almeida

$$
\text { DISSERTAÇÃO DE MESTRADO }
$$

Programa de Pós-Graduação em Geoquímica e Geotectônica

São Paulo 


\title{
UNIVERSIDADE DE SÃO PAULO INSTITUTO DE GEOCIÊNCIAS
}

\section{Numerical model of alluvial terrace and valley evolution applied to the Quaternary of Central Amazonia}

\section{ARIEL HENRIQUE DO PRADO}

\author{
Dissertação apresentada ao Programa \\ Geociências (Geoquímica e \\ Geotectônica) para obtenção do título de \\ Mestre em Ciências
}

Área de concentração: Geotectônica

Orientador: Renato Paes de Almeida

\section{São Paulo}


Autorizo a reprodução e divulgação total ou parcial deste trabalho, por qualquer meio convencional ou eletrônico, para fins de estudo e pesquisa, desde que citada a fonte.

Serviço de Biblioteca e Documentação do IGc/USP

Ficha catalográfica gerada automaticamente com dados fornecidos pelo(a) autor(a) via programa desenvolvido pela Seção Técnica de Informática do ICMC/USP

Bibliotecários responsáveis pela estrutura de catalogação da publicação: Sonia Regina Yole Guerra - CRB-8/4208 | Anderson de Santana - CRB-8/6658

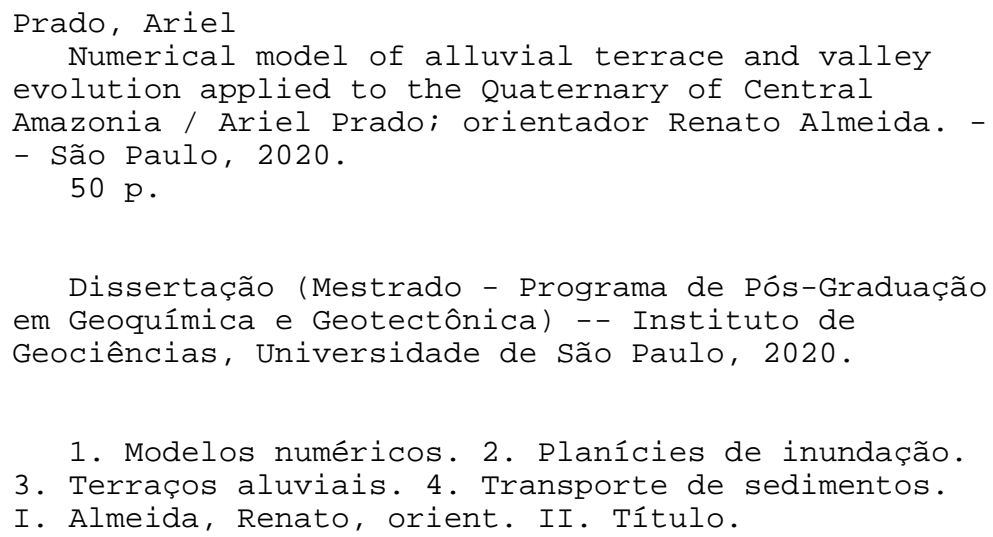

1. Modelos numéricos. 2. Planícies de inundação. 3. Terraços aluviais. 4. Transporte de sedimentos.

I. Almeida, Renato, orient. II. Título. 
UNIVERSIDADE DE SÃO PAULO INSTITUTO DE GEOCIÊNCIAS

NUMERICAL MODEL OF ALLUVIAL TERRACE AND VALLEY EVOLUTION APPLIED TO THE QUATERNARY OF CENTRAL AMAZONIA

\section{ARIEL HENRIQUE DO PRADO}

Orientador: Prof. Dr. Renato Paes de Almeida

Dissertação de Mestrado

$N^{\circ} 851$

COMISSÃO JULGADORA

Dr. Renato Paes de Almeida

Dr. Victor Sacek

Dr. Pedro Fonseca de Almeida e Val

SÃO PAULO

2020 


\section{AGRADECIMENTOS}

Gostaria de agradecer primeiramente ao meu orientador Prof. Dr. Renato Paes de Almeida, que participou de minha formação desde a graduação em Geofísica, onde me orientou na Iniciação Científica. Agradeço pela intensa participação na proposta e desenvolvimento deste trabalho e pelo apoio em momentos de dificuldade.

Agradeço aos integrantes do grupo de pesquisa Mocó, Carlos Eduardo Manjon Mazoca, Geovana Leite Geraldo, Larissa Natsumi Tamura, Liliane Janikian e Lucas Corrêa D'Almeida que participaram de momentos chave no desenvolvimento deste trabalho. E principalmente agradeço ao companheiro de trabalho Cristiano Padalino Galeazzi que participou de discussões cruciais para o desenvolvimento deste trabalho e se disponibilizou a revisar detalhadamente toda a dissertação.

Agradeço à Fundação de Amparo à Pesquisa do Estado de São Paulo (FAPESP - Proc. 2018/02197-0) pela concessão da bolsa de mestrado e pelo apoio financeiro para a realização desta pesquisa. Também agradeço a Coordenação de Aperfeiçoamento de Pessoal de Nível Superior (CAPES) pelo apoio. Aos professores, funcionários e alunos do IGc-USP pela amizade e pela ajuda em diferentes necessidades durante o mestrado.

Agradeço à minha companheira Beatriz pelo seu apoio, carinho e paciência durante todo o desenvolvimento deste trabalho. Ao meu pai Antônio e à minha mãe Heloísa por sua confiança e apoio desde a minha infância. E a todos os amigos que de forma indireta me ajudaram durante todo esse percurso. 


\section{ABSTRACT}

The study of the mechanisms which shape the central Amazonia alluvial landscapes in the long term is of great relevance for the reconstruction of the past drainage systems and biogeographical patterns in the region. Current conceptual models for the Quaternary are based on paleogeographic interpretations of the vast alluvial terrace systems found in the region and on the role of external forcings, such as climate change, eustatic variation and neotectonics. In that context, evaluating, from a quantitative perspective, the interactions between alluvial dynamics and those external controls is key to constraint the interpretation of the morphological elements and sedimentary deposits. Therefore, the aim of this dissertation is to present a new numerical model capable of quantitatively testing hypotheses and conceptual models concerning the evolution of the great alluvial plains in Central Amazonia during the Quaternary. The model operates at a spatial of $10^{5} \mathrm{~km}^{2}$ and a temporal scale of $10^{5}$ years, and presents a novel approach to simulate the lateral erosion of channel banks, coupled with a conventional model of erosion and deposition of sediments on channel beds. Scenarios were tested which simulate the modern configuration of the region containing the Solimões river and its tributary Japurá River, but with altered rainfall rates, rates of lateral erosion, base-level variation, sediment input and subsidence of specific areas in the grid to simulate the development of grabens. The results reveal that lateral erosion in an essential mechanism not only for the formation of alluvial plains and widening of valleys but also for the shape of the river long profiles, thus significantly altering the landscape evolution. In-valley incisional and aggradational processes resulted from three different mechanisms: base-level variation, changes in rainfall rate and shifts in the trunk river position, which modified the local base level for the tributaries. In the case of in-valley aggradation due to base-level rise of a drop in the rainfall rate, the trunk river, with great sediment flux, is capable of infilling the new accommodation space. Smaller tributaries, on their turn, cannot respond to the elevation of the trunk river alluvial plain and develop ria lakes. An important effect recognized in the model is an increase in the rate of valley widening by lateral erosion during deposition and 
aggradation, since the augmented avulsion rates at that stage result in a higher probability of valley margin erosion. The graben formation scenario reveals that when these tectonic features occur in the trunk river valley, they are rapidly filled and their margins are reworked by erosion, thus leaving no evidence of their presence in the landscape surface. Grabens developed on higher terraces, on the other hand, result in preserved morphological elements. As a whole, these results reveal processes and relations that have not been considered in current conceptual models, while enabling quantitative testing of the hypotheses concerning the paleogeography and the role of external forcings in the evolution of large alluvial plains.

Key-words: Numerical models, floodplain, alluvial terraces, lateral erosion, sediment transport, Solimões and Juruá Rivers. 


\section{RESUMO}

O estudo dos mecanismos que, a longo prazo, moldam a paisagem aluvial na Amazônia Central é de grande relevância para a reconstrução da evolução dos sistemas de drenagem e dos padrões biogeográficos dessa região. Modelos conceituais vigentes para o Quaternário baseiam-se em interpretações paleogeográficas dos amplos sistemas de terraços aluviais encontrados na região e na atuação de controles externos como mudanças climáticas, variações eustáticas e neotectônica. Nesse contexto, a avaliação quantitativa da interação entre a dinâmica aluvial e tais controles externos é necessária para uma interpretação mais consistente dos elementos morfológicos e depósitos sedimentares. Assim, o objetivo deste trabalho é apresentar um novo modelo numérico que é capaz de testar quantitativamente hipóteses e modelos conceituais sobre a evolução das grandes planícies aluviais da Amazônia Central no Quaternário. Esse modelo, que trabalha em uma escala espacial de $10^{5} \mathrm{~km}^{2}$ e em uma escala temporal de $10^{5}$ anos, apresenta uma nova abordagem simplificada, capaz reproduzir a erosão lateral de bancos por canais, acoplada a um modelo de erosão de fundo de canal, deposição e transporte de sedimentos. Foram testados cenários que simulam a situação atual da região do Rio Solimões e seu afluente Juruá, com diferentes condições de taxas pluviométricas, taxas de erosão lateral, variações no nível de base, aporte externo de sedimentos e subsidência em áreas específicas para simular a formação de grabens. Os resultados mostraram que a erosão lateral é um mecanismo essencial não apenas para a formação de planícies de inundação e abertura de vales, mas também para a determinação dos perfis longitudinais de equilíbrio dos rios, alterando significativamente a evolução da paisagem. Processos de incisão e agradação em vales resultaram de três diferentes mecanismos: variações do nível de base, alterações na precipitação pluviométrica e modificações na posição do rio tronco, alterando o nível de base local de tributários. No caso da agradação sedimentar nos vales por subida do nível de base ou redução da precipitação, o rio tronco, devido ao seu alto fluxo sedimentar, é capaz de preencher o novo espaço de acomodação enquanto que pequenos tributários não conseguem 
responder rapidamente a elevação do rio tronco e formam rias fluviais. Um importante efeito reconhecido no modelo é o aumento da taxa de alargamento de vales por erosão lateral durante a agradação, já que taxas aumentadas de avulsão resultam em maior probabilidade de erosão das margens dos vales. O cenário com formação de grabens mostrou que quando estes ocorrem dentro dos vales do rio tronco são rapidamente preenchidos e suas margens retrabalhadas por erosão, não deixando evidências se sua existência na superfície, já quando ocorrem nos terraços têm suas formas preservadas. O conjunto destes resultados revelam processos e inter relações não consideradas nos modelos conceituais vigentes e permitem testes quantitativos de hipóteses sobre a paleogeografia e o papel de controles externos na evolução de grandes planícies aluviais.

Palavras-Chave: Modelos numéricos, planícies de inundação, terraços aluviais, erosão lateral, transporte de sedimentos, rios Solimões e Juruá. 


\section{CONTENTS}

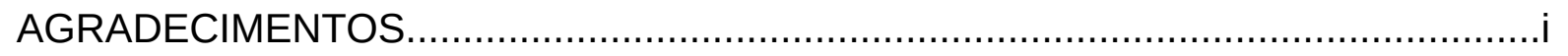

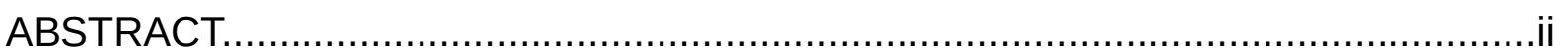

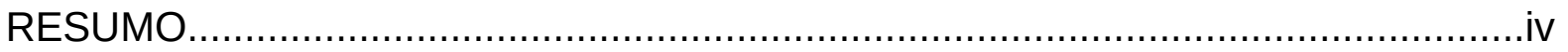

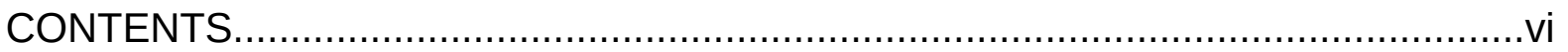

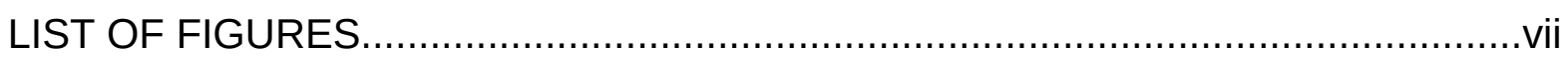

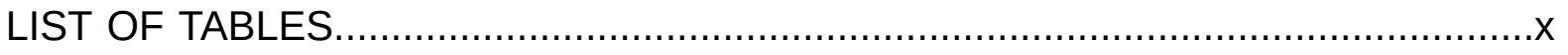

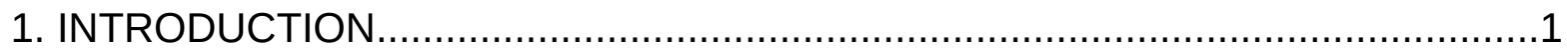

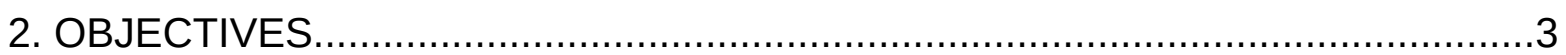

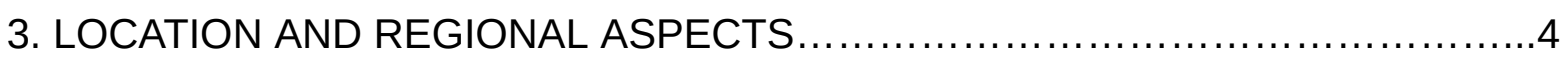

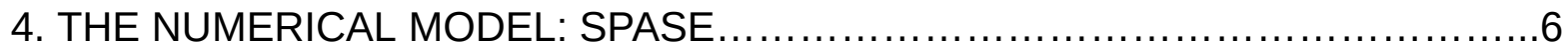

4.1 Mathematical description of the Earth surface processes...................7

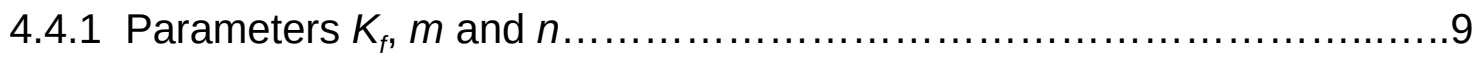

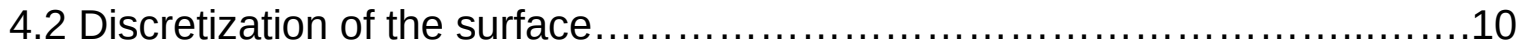

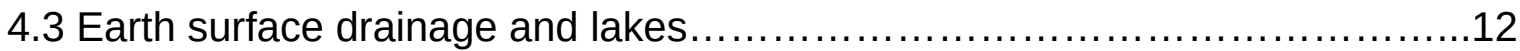

4.4 Formulation of the Earth surface processes in the hexagonal grid............16

4.4.1 Discretization of lateral erosion process.............................

4.4.2 Fluvial processes of transport, deposition and bed erosion..............20

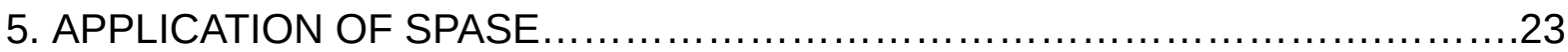

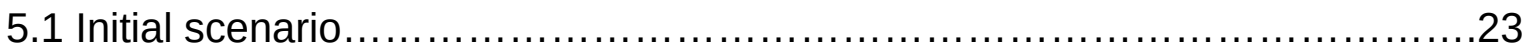

5.2 The effects of different lateral erosion parameters and base level drop........26

5.3 The effects of different river sediment flux input...........................

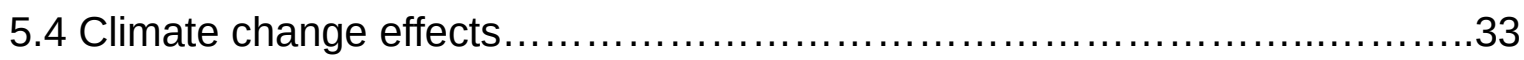

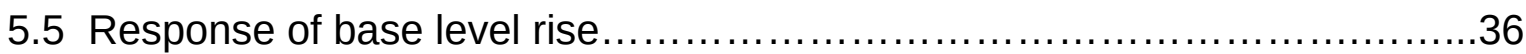

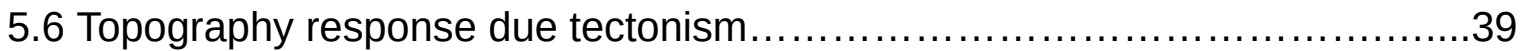

5.7 Effects of change in the position of Solimões river......................... 42

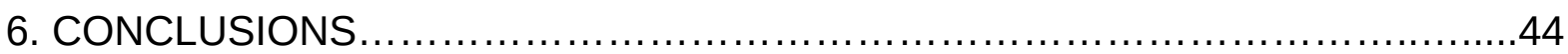

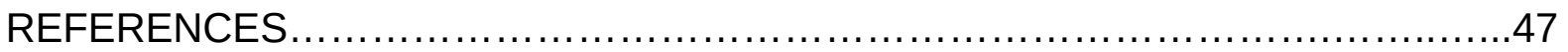




\section{LIST OF FIGURES}

Figure 3.1: Topography of the studied region with key geographical designations over a Digital Elevation Model image highlighting variations on the alluvial terrains. Red square represents the region of Juruá river that is reproduced in the model......................................

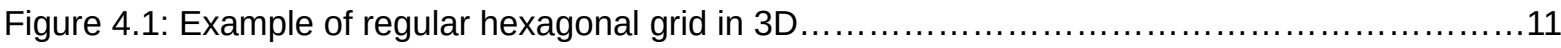

Figure 4.2: Flowchart of SPASE. The time is counted by the variable $t$, the time step is defined by $d t$ and the total time of modelling is $t_{f}$ 12

Figure 4.3: Example of a drainage network in hexagonal grid. Blue lines represent the drainage where thickness are relative to its discharge and the arrows indicate the direction of water flow .13

Figure 4.4: Flowchart of drainage and lakes calculation .14

Figure 4.5: Empirical relation between water discharge and river width in Amazonia. Blue dots are the empirical data obtained from Brazilian Water Agency (A.N.A.). Orange line is the exponential curve fitted to the data. 18

Figure 4.6: Example of before-after scenario in a hexagonal grid in a time step of lateral erosion process. Each cell has three geometrical parameters, channel area in blue $\left(A_{\text {channel }}\right)$, floodplain area in light green $\left(A_{\text {tloodplain }}\right)$ and terrace area in dark green $\left(A_{\text {terrace }}\right)$. After the time step, the floodplain area in each cell increases due to lateral erosion 20

Figure 5.1: Initial scenario for this study case. Blue lines represent channels, where the thickness is proportional to the discharge. In the upper right corner, a river with discharge similar to the Jurua River $\left(4.750 \mathrm{~m}^{3} / \mathrm{s}\right)$ is inputted, and in the lower right corner a river with discharge similar to the Solimões River $\left(54.940 \mathrm{~m}^{3} / \mathrm{s}\right)$ is inputted. Sink cells are in the lower left corner locked at an altitude of 140 meters. Cells are regular hexagons with 4.000 meters of side and the total number of cells is 10 thousand. The values of height are to an arbitrary referential and not to the modern sea level. In comparison with the actual topography and drainage of the region of confluence between Juruá and Solimões River, the north points down in this representation. 
Figure 5.2: Elevation profile of actual Jurua River in the trench shown in the red square in Figure 3.1, obtained in Google Earth after a low-pass filter. Mean slope $\sim 14 \mathrm{~cm} / \mathrm{km}$

Figure 5.3: Elevation profile of the main tributary in the initial topography compared to the elevation profile of the modern Juruá River (Dark blue line). The discharge of the main tributary in the model (Light blue line) shows the confluence with the trunk river when increases from $6000 \mathrm{~m}^{3} \mathrm{~s}^{-1}$ to $\sim 60000 \mathrm{~m}^{3} \mathrm{~s}^{-1}$ .25

Figure 5.4: Topography $\left(h_{\text {terrace }}\right)$ and drainage evolution in an incisive scenario for $L_{l e}=10^{1}$ and $10^{2} \mathrm{~m}$. With $t=100,1000$ and 5000 years. The development of the valleys from the lower left corners of the images appears in blue tones with lower elevation.

Figure 5.5: Topography $\left(h_{\text {terrace }}\right)$ and drainage evolution in an incisive scenario for $L_{l e}=10^{3}$ and $10^{4} \mathrm{~m}$. With $t=100,1000$ and 5000 years. From the lower left corners of the images, the development of the valleys appears in blue tones with lower elevation..... 28

Figure 5.6: Topography and drainage response at $\mathrm{t}=10 \mathrm{kyin}$ an incisive scenario for $L_{l e}=10^{1}, 10^{2}, 10^{3}$ and $10^{4} \mathrm{~m}$. The width of the developed valleys in each resulting topography scenario is shown. Note that wider valleys develop with larger $L_{l e}$

Figure 5.7: Elevation profiles ( $h_{\text {channel }}$ ) of the main tributary resulted with $L_{l e}=10^{1}, 10^{2}, 10^{3}$ and $10^{4} \mathrm{~m}$, at $\mathrm{t}=10 \mathrm{ka}$, in comparison with initial elevation profile. By increasing $L_{l}$ the response of the elevation profile changes to a more incisive scenario, due to the decrease of the sediment volume laterally eroded by the channels .30

Figure 5.8: Elevation profiles of the main tributary from SPASE (Red line) with different values of sediment input, for $\mathrm{t}=10 \mathrm{ky}$ and elevation value of $h_{\text {channel }}$ in each cell, in comparison with elevation profile of actual Juruá River (Dark blue line). The water discharge of the main tributary in the model is represented by the light blue line. The best fit line adjustment of the elevation profile is to the value of $0.47 \mathrm{~m}^{3} \mathrm{~s}^{-1}$ to the sedimentary input....... 32

Flgure 5.9: Elevation profiles of the main tributary for different values of rainfall in the grid at $t=10 \mathrm{ky}$. The values of rainfall tested are 100,500, 1000, 1500, 2000 and $3000 \mathrm{~mm} \mathrm{yr}^{-1}$. The initial profile of the tested scenarios is shown in blue dashed line. The resulting profiles show that when the rainfall increases the erosion takes place in all the profile, and when the rainfall decreases deposition takes place. 
Figure 5.10: Comparison of the resulting topography of scenarios with rainfall of 100 and $3000 \mathrm{~mm} \mathrm{y}^{-1}$ at $\mathrm{t}=10 \mathrm{ky}$. The result with rainfall of $3000 \mathrm{~mm} \mathrm{yr}^{-1}$ shows that the smaller tributaries perform more incision with rainfall increase. An interesting aspect in the result with rainfall of $100 \mathrm{~mm} \mathrm{yr}^{-1}$ is the formation of a small river valley lake (fluvial ria) next to the head of the main tributary, due the deposition caused by the decrease of rainfall. .35

Figure 5.11: Response of the topography in the model to a base level rise. The sink cells (lower left corner) start with 100 meters of elevation and rise at a rate of $10 \mathrm{~m} \mathrm{ka}^{-1} \mathrm{until} \mathrm{t}=5 \mathrm{ka}$, after that they maintain their height constant until $t=10 \mathrm{ky}$. Formed lakes in figures with $t=5,7$ and $10 \mathrm{ky}$ are shown as connected smooth blue hexagons. The lakes formed on the lower end of tributaries of the trunk river are known as fluvial rias. .37

Figure 5.12: Evolution of the elevation profile of the main tributary in a scenario with base level rise. The profile had small changes next to the river head, showing even a remaining incision until $t=500$ years. The response to the base level rise is an increase in elevation of the profile, with variation increasing downstream of the river, even after the base level stop at $\mathrm{t}=$ $5 \mathrm{ky}$ .38

Figure 5.13: Topographic and drainage response due to tectonism. The initial topography at $t=0$ years shows the regions where, in the cells inside the rectangles, a subsidence of $0.5 \mathrm{~m} \mathrm{ka}^{-1}$ occurs for $30 \mathrm{ky}$

Figure 5.14: Evolution of elevation profile of the main tributary with an initial scenario where the trunk river is inputted in a cell next to the input of the main tributary. This result shows an incision at the head of the main tributary.

Figure 5.15: Evolution of topography with an initial scenario where the trunk river is inputted in a cell next to the input of the main tributary. A fluvial ria is formed, at $t=2 \mathrm{ka}$, in the old Solimões River floodplain due the volume of sediment relocated.... 


\section{LIST OF TABLES}

Table 4.1: Discharge and sediment flux data from the Juruá and Solimões Rivers, from Filizola and Guyot (2009), and slope of respective floodplains obtained from Google Earth elevation model. The units of sediment flux data obtained were converted to from $t^{9} \mathrm{y}^{-1}$ to $\mathrm{m}^{3} \mathrm{~s}^{-1}$ considering the density of the suspended sediment equal to $2300 \mathrm{~kg} \mathrm{~m}^{-3}$ 10

Table 4.2: Values of the parameters $K_{f}$ for Solimões and Juruá rivers for different values of $m$ in a way that the resulting values of $Q_{\text {eqb }}$ (given by equation 4.1) is always equal to the measured

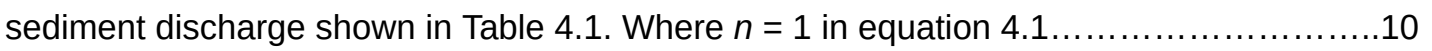

Table 4.3: Geometrical parameters of a cell to calculate the Earth surface processes. .17

Table 5.1: Values of the parameters used in most of the tested scenarios described in the following sections. 


\section{INTRODUCTION}

The lowlands of central Amazonia contain one of the biggest systems of alluvial deposits on Earth, composing extensive fluvial terraces formed during the late Pleistocene (e.g. Rossetti et al. 2005, Pupim et al. 2019). Although these deposits are of great relevance in the reconstruction of both the physical landscape evolution and the patterns of biotic diversity in the region (e.g. Ribas et al. 2012, 2019, Pupim et al, 2019), the mechanisms that control the long-term landscape evolution of this system are still a matter for discussion. Processes that shape alluvial landscapes in the Amazonia are related to fluvial sediment transport (erosional and depositional processes) and tectonism (e.g. Rossetti et al. 2005), but the explicit effects of climatic and tectonic dynamics in the behaviour of large-scale fluvial systems are not yet constrained.

Terrace systems have a great importance in the study of such mechanisms because they store sediments that allow the geochronological dating while recording grain-size, paleogeography, transport direction and sense. Thus, allowing for the construction of the tectono-sedimentary evolution. Numerical models bear a great potential to integrate varied sources of information about these terrace systems in coherent scenarios and evaluate the contribution of specific controls on the landscape dynamics. Nevertheless, the regional scale of these deposits and the specific processes that are involved in the deposition of widespread fluvial sediments and the incision of valleys hamper the direct application of both physically-based hydrodynamic stream flow models (e.g. Nicholas et al., 2012) and continental-scale stream-power law (e.g. Sacek, 2014) approximations to erosion and deposition.

In fact, conceptual models and hypotheses concerning the Pleistocene terrace system of central Amazonia involve two main aspects of fluvial dynamics, occurring at different geological time scales: the long term ( $10^{7}$ years) patterns of environmental change due to the infill of the Andean-related foreland and dynamic topography basins by the alluvial sediments and the establishment of a transcontinental drainage system (e.g. Hoorn et al., 2010), and the short term (104 years and less) effects of sea-level (e.g. Irion \& Kalliola, 2010) and possibly climate 
(e.g. Ribas et al. 2019) change. Although the conceptual models for longer time scales have been quantitatively evaluated in continental-scale numerical models (Sacek, 2014, Bicudo et al., 2019), the short-term effects of climate and eustasy require a novel approach that considers the particularities of that specific time and geographical scales.

One of the processes that the known large-scale and long-term models (e.g. Sacek, 2014, Bicudo et al., 2019) do not reproduce is the lateral erosion of valley margins and older terraces resulting from lateral migration of channels. This process is essential to the formation and widening of the in-valley floodplains, which is an important element in the central Amazonia because it is in the floodplains that Várzea and Igapó biomes develop. Additionally, including lateral erosion in landscape evolution models might affect the sediment load to water discharge ratio and, more importantly, the along-stream variation of that ratio, with implication for the river long profile shape, which on its turn controls the sedimentary response to base-level variations (e.g. Davis, 1902, Shanley \& McCabe, 1993, Quirk, 1996)

In order to develop a tool to quantitatively test conceptual scenarios for the evolution of the alluvial systems in central Amazonia, the present work introduces a new numerical model, tailored to reproduce alluvial processes at a $10^{5}$ years time scale at a $10^{5} \mathrm{~km}^{2}$ spatial scale. The model (SPASE - Sedimentary Processes and Alluvial Systems Evolution) implemented in Python, introduces a new simplified approach to reproduce lateral erosion and terrace formation coupled with a erosion/deposition/transport model. The model was run with varied pluviosity rates, base level change and sedimentary input to understand the influence of the erosional and depositional processes in the evolution of the landscape in central Amazonia, and quantitatively test the role of eustasy, tectonics and climate change in establishing the observed morphological elements in the region. 


\section{OBJECTIVES}

The main objective of this work is to present a new numerical model of landscape evolution which considers not only vertical erosion and deposition on each model cell but also the effects of lateral bank erosion on older deposits in nearby cells to the channels.

The secondary objective is to apply such a model to scenarios of alluvial landscape evolution in central Amazonia during the Quaternary and test basic conceptual models about the possible roles of base-level changes, climatic change and local tectonics in determining the morphological features observed in the region. 


\section{LOCATION AND REGIONAL ASPECTS}

Several of the largest rivers on Earth are found in the alluvial lowlands of central Amazonia, such as the Amazonas (209.000,0 m $\mathrm{m}^{3} \mathrm{~s}^{-1}$ mean annual discharge at the mouth), Negro $\left(28.000,0 \mathrm{~m}^{3} \mathrm{~s}^{-1}\right)$, Japurá $\left(18.600,0 \mathrm{~m}^{3} \mathrm{~s}^{-1}\right)$, Purus $\left(11.000,0 \mathrm{~m}^{3}\right.$ $\mathrm{s}^{-1}$ ) and the Juruá $\left(8.440,0 \mathrm{~m}^{3} \mathrm{~s}^{-1}\right)$, among others (Latrubesse, 2005). Those rivers are also responsible for large volumes of sediment transported to the sea, at a rate of about $10^{8}$ ton year-1 (Filizola and Guyot, 2009). Thus the rivers that flow in this region are largely responsible for shaping the topography. The Digital Elevation Model (DEM), derived from the Shuttle Radar Topography Mission (SRTM), of the central Amazon shows low topographic gradients and the presence of periodically flooded areas (floodplains) in valleys incised on onder alluvial deposits (terraces) (Figure 3.1). These environments are related to specific forest types, controlled by the flood regime to which they are subject. Never-flooded terraces bear Terra Firme forest and seasonally flooded plains bear either Igapó or Várzeas forest, depending on the amount of suspended sediment load delivered by the river which implies varied nutrient content (Sioli, 1984).

The floodplains and terraces observed in the region have their formation largely influenced by sedimentary erosional and depositional processes. Before about $50 \mathrm{ka}$, areas that are now terraces were part of a large depositional system in which rivers flowing in this region had high deposition and avulsion rates at a higher base level (Pupim et al., 2019, Wilkinson et al., 2010). During this stage, flooded environments covered much larger areas, as they were not restricted to incised valleys. Due to an adjustment of the river long profile to a lower base level or a relative increase in water discharge to sediment flow ratio, the main rivers incised to reach their modern position and promoted valley widening through lateral erosion and channel migration processes. 


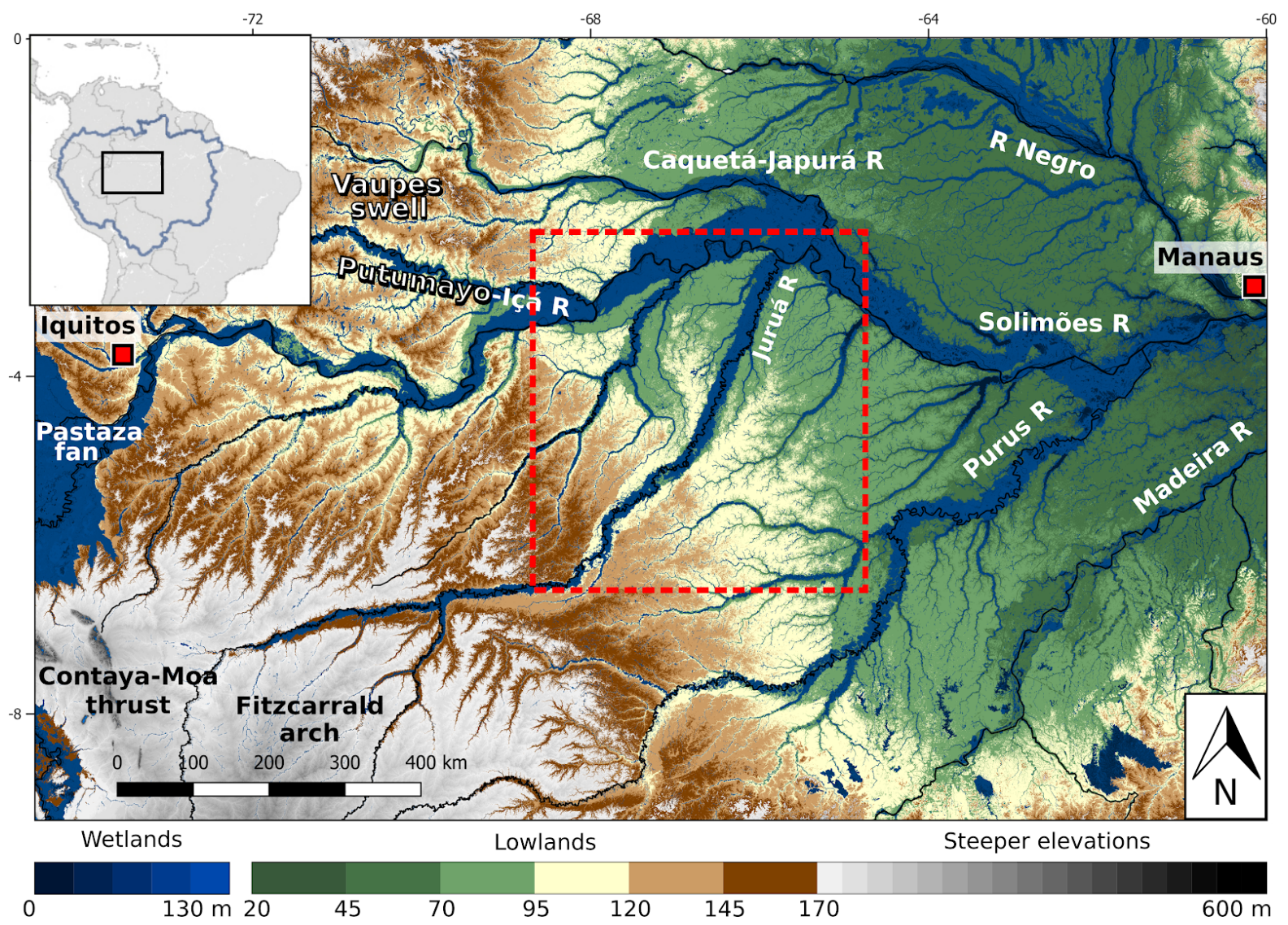

Figure 3.1: Topography of the studied region with key geographical designations over a Digital Elevation Model image highlighting variations on the alluvial terrains. Red square represents the region of Juruá river that is reproduced in the model.

Deposition age dating of sediments from floodplains next to the mouth of Juruá river indicates ages younger than $45 \mathrm{ka}$, while the ages available for interfluvial terraces reveal deposition ages of about 50 ka for the top of the youngest terrace system (Pupim et al., 2019). This implies that the events of incision in this region happened about $50 \mathrm{ka}$.

In this work, scenarios will be tested that try to reproduce conditions similar to those in the valleys and interfluves in the region of the Juruá-Solimões confluence (Red square in Figure 3.1). This region is a representative area to understand how the erosional and depositional processes responded to external controls in determining landscape evolution across the central Amazonia alluvial plain. 


\section{THE NUMERICAL MODEL: SPASE}

As reviewed by Coulthard (2001), the first numerical models developed to study landscape evolution date back to the 70's, with the pioneer work by Anhert (1976). Due to the increasing power and availability of computers, more accurate models could be developed in later years (e.g. Kirkby, 1987, Howard, 1994). These new models allowed the study of the interaction between fluvial erosional and depositional processes, slope processes, tectonic uplift and subsidence, climate and lithology with the evolution of topography and drainage systems.

A numerical model for this case study must comprehend the complexity generated by the interaction of factors operating at different spatial and temporal scales. For example, the long-range of processes occurring through a channel, including all the hydrodynamic processes that cause sediment transport and erosion whereas mass transportation in hillslopes occur in a short-range (Beaumont, 1992). Different approaches to deal with these problems have been presented in the literature, such as models with irregular grids that increase the resolution in channel regions (e.g. Braun and Sambridge, 1997, Tucker et al.,2000), models that use different time scales in the same grid for cells near to channels cells in hillslopes (e.g. Coulthard et al., 1999) or models that use a subgrid to represent channel cells (e.g. Tucker and Slingerland, 1994). The spatial resolution is also an important factor, because the greater the number of cells per area is, the more the model needs to reproduce in detail hydrodynamic phenomena, being more computationally expensive. An example of such a case is the work of Van De Wiel et. al. (2007), which presents a high resolution model of alluvial environments, capable of simulating effects of lateral channel migration and terrace formation: in a test scenario in an area of approximately $4 \mathrm{~km}^{2}$ simulating 171 days the processing time was 42 hours.

The present work aims to study the influence of surface processes in the landscape evolution of alluvial systems in central Amazonia in a time scale of thousands of years in an area of approximately $10^{5} \mathrm{~km}^{2}$. This is done by equations that simplify the true nature of sediment transport-erosion-deposition in rivers, which represent the first-order property of fluvial sediment transport (Beaumont, 1992). The 
large-scale and long-term scenarios to be simulated require a simplified model, because a model based on hydrodynamics physics would demand a great amount of computational time, making it infeasible.

Therefore, the adopted approach was to adapt the stream power law concept (e.g. Beaumont 1992) of erosion-sedimentation-transport modeling to the specific problem. That adaptation is based on two main additions: (1) a routine to simulate lateral erosion at channel margins and (2) an approach to consider the properties of a channel within a cell, which does not necessarily occupy the whole cell area. The latter approach was achieved by recording two values of elevation (one for the active alluvial plain and the other for possible older and higher terraces within the same cell), and three values of area, thus considering the relative proportion of channel, alluvial plain and older terraces within each cell.

The following sections present the mathematical basis of the proposed landscape evolution model, SPASE (Sedimentary Processes and Alluvial System Evolution), and how the numerical treatment of each process is done. This model simulates the effects of Earth surface processes, here understood as subaerial processes of erosion, transport and deposition of sediments, in alluvial landscapes.

\subsection{Mathematical description of the Earth surface processes}

To simulate mass transport, previous works (e.g. Beaumont et al. 1992, Sacek, 2011, 2014) considered both fluvial processes, such as long distance mass transport by rivers, and slope processes, such as local mass transport by landslide. Since the Amazon alluvial system here simulated has very low slopes and its area is completely vegetated, making hillslope effects irrelevant, this work only considers the effects of fluvial processes. To simulate fluvial processes, Beaumont et al. 1992 proposed an adaptation of the stream power law, where for a given channel the carrying capacity of sediment, $Q_{\text {eqb }}$, which would be equivalent to the maximum volume of sediment per unit time $\left[\mathrm{L}^{3} \mathrm{~T}^{-1}\right]$ that the channel can carry, is given by the equation (Same formulation as Braun, 2006):

$$
Q_{e q b}=K_{f} Q_{r}^{m} S^{n}
$$


Where $Q_{r}$ is the water discharge from the channel $\left[\mathrm{L}^{3} \mathrm{~T}^{-1}\right], S$ is the slope $[\mathrm{L}$ L-1]. It is important to note that to ensure dimensional consistency of the equation the dimension of constant $K_{f}$ is $\left[\mathrm{T} \mathrm{L}^{-3}\right]^{\mathrm{m}-1}$. Possible values and physical meaning of the constants $K_{f}, \mathrm{~m}$ and $\mathrm{n}$ are discussed below (Section 4.1.1). Sediment erosion, deposition and transport (suspended and bottom) in a channel is given by the equation below, where the erosion/deposition rate is assumed to be proportional to the difference between the carrying capacity $\left(Q_{\text {eqb }}\right)$ and sediment discharge, $Q_{\text {sed }}\left[\mathrm{L}^{3}\right.$ $\left.\mathrm{T}^{-1}\right]$, in the channel (Braun, 2006) :

$$
\frac{\delta h}{\delta t}=-\frac{1}{W L_{f}}\left(Q_{e q b}-Q_{s e d}\right)
$$

Where $W$ is the channel width [L] and $L_{f}$ is the erosion/deposition length scale [L], which is a material property. From equation 4.2 , if $Q_{\text {sed }}<Q_{\text {eqb }}$, erosion takes place and $L_{f}$ is assumed to be the length scale property of the river bed load, $L_{a}$. If $Q_{\text {sed }}>Q_{e q b}$, deposition takes place and $L_{f}$ is assumed to be the length scale property of the suspended load in the river, $L_{s}$, where $L_{s}<L_{a}$.

This work introduces a new approach to reproduce lateral erosion of channels, where the local volume of sediment that a channel can laterally erode, $B$ $\left[\mathrm{L}^{3}\right]$, is given by the equation:

$$
\frac{\delta B}{\delta t}=A_{l e}\left(\left[h_{\text {terrace }}-h_{\text {channel }}\right]+h_{\text {depth }}\right)
$$

Where $h_{\text {terrace }}$ is the height of the terrace adjacent to the channel [L], $h_{\text {channel }}$ is the height of the channel surface [L], $h_{\text {depth }}$ is the depth of the channel [L] and $A_{l e}$ is the rate of area laterally eroded per time $\left[\mathrm{L}^{2} \mathrm{~T}^{-1}\right]$ defined as:

$$
A_{l e}=\frac{Q_{e q b}}{L_{l e}}
$$


Where $Q_{e q b}$ is the carrying capacity of the channel $\left[\mathrm{L}^{3} \mathrm{~T}^{-1}\right], L_{l e}$ is the lateral erosion length scale which depends on eroded material [L].

\subsubsection{Parameters $K_{f}, m$ and $n$}

Values and units of measurements of parameters $K_{f}, m$ and $n$ have varied greatly and have been poorly defined in previous works. Therefore, this section investigates what values of these parameters best reproduce scenarios similar to modern configuration. In equation 4.1, the constant $K_{f}$ is the dimensional transport coefficient that adjusts the carrying capacity $\left(Q_{\text {eqb }}\right)$. Constants $m$ and $n$ determine whether the discharge and slope have a linear $(m=n=1)$ or a power $(m \neq 1$ and $n \neq$ 1) relation with $Q_{\text {eqb }}$. In this work, the values for $m$ and $n$ are defined as $m \geq 1$ and $n$ $=1$, based on theoretical experiments and field observations of Whipple and Tucker (2002).

To define the best parameters of $K_{f}$ and $m$, the equation 4.1 is applied using the measured slope (obtained from the SRTM digital elevation model), water discharge and sediment discharge data from modern Solimões and Juruá rivers (obtained from Filizola and Guyot, 2009) (Table 4.1). Definition of the values of the parameters is based on two assumptions: (i) in an alluvial river reach in a state of near-equilibrium, where its elevation profile presents only small changes over time, the calculated carrying capacity $\left(Q_{\text {eqb }}\right)$ needs to be equal to its measured suspended sediment discharge; (ii) the values of $K_{f}$ and $m$ are those that when applied in the cases of the Solimões and Juruá River, both $Q_{e q b}$ result in their respective measured sediment discharge. Table 4.2 shows the development of such reasoning and tests different values of the parameters to reach the values that respects the two assumptions. In this table, $m$ varies from 1.0 to 1.7 and $K_{f}$ of both Solimões and Juruá varies accordingly so that $Q_{\text {eqb }}$ equals the measured sediment discharge. The values of $K_{f}$ calculated for Solimões and Juruá Rivers are equal to each other $\left(K_{f}=\right.$ 0.0054 ) only in the case of $m=1.54$, suggesting that these are the best values for the two parameters for this study case. 
Table 4.1: Discharge and sediment flux data from the Juruá and Solimões Rivers , from Filizola and Guyot (2009), and slope of respective floodplains obtained from Google Earth elevation

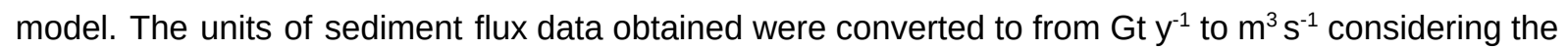
density of the suspended sediment equal to $2300 \mathrm{~kg} \mathrm{~m}^{-3}$.

\begin{tabular}{|l|l|l|l|}
\hline & Sediment flux $\left(\mathrm{m}^{3} \mathrm{~s}^{-1}\right)$ & $\begin{array}{l}\text { Annual mean } \\
\text { discharge }\left(\mathrm{m}^{3} \mathrm{~s}^{-1}\right)\end{array}$ & $\begin{array}{l}\text { Slope } \\
(\mathrm{cm} \mathrm{km})\end{array}$ \\
\hline Solimões & 6.50 & 54940.0 & 6.0 \\
\hline Juruá & 0.35 & 4750.0 & 14.0 \\
\hline
\end{tabular}

Table 4.2: Values of the parameters $K_{f}$ for Solimões and Juruá rivers for different values of $m$ in a way that the resulting values of $Q_{\text {eqb }}$ (given by equation 4.1) is always equal to the measured sediment discharge shown in Table 4.1. Where $n=1$ in equation 4.1.

\begin{tabular}{|l|l|l|l|l|l|}
\hline$m$ & $K_{f}$ - Solimões & $K_{f}$-Juruá & $m$ & $K_{f}$ - Solimões & $K_{f}$ - Juruá \\
\hline 1.0 & 1.97 & 0.52 & 1.5 & 0.0084 & 0.0076 \\
\hline 1.1 & 0.66 & 0.22 & 1.54 & 0.0054 & 0.0054 \\
\hline 1.3 & 0.074 & 0.041 & 1.6 & 0.0028 & 0.0032 \\
\hline 1.4 & 0.025 & 0.017 & 1.7 & 0.00094 & 0.0014 \\
\hline
\end{tabular}

\subsection{Discretization of the surface}

In numerical models, the discretization of the surface is usually done by the division of the topography into cells, which are small portions of area represented by an array with information such as coordinates, area and height. Two common approaches to define the shape of the cells are: (1) regular grid with quadratic cells, with the disadvantage of the limited possible directions between connected cells, causing artificial simetries (e.g. Beaumont 1992, Van De Wiel et al., 2007), and (2) irregular grids formed by Voronoy cells, which eliminate the artificial symmetry observed in regular grids but do not allow a control the cell sides length (e.g. Sacek, 2014).

To overcome the above disadvantages, the SPASE model uses a regular hexagonal grid to represent the surface (Figure 4.1). The main reason of doing so is the necessity of controlling the length of the cells sides, because the width of a river inside a cell needs to be smaller than the side of the cell to which it is flowing, in 
order to guarantee only one flow direction. Additionally, the regular hexagonal grid gives six possible directions of flow, instead four in quadratic cells.

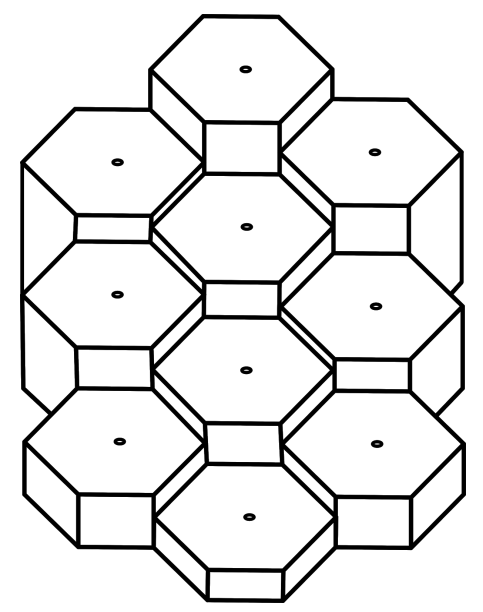

Figure 4.1: Example of regular hexagonal grid in 3D.

Figure 4.2 shows the SPASE model work flowchart. The first step is the definition of geometric parameters, such as size and number of cells of the grid, and constants of the equations that govern the surface processes. To create a regular hexagonal grid requires some parameters, such as the length of the cell side and the number of cells in the $x$ and $y$ axes.

The grid is created after the definition of the parameters, and each cell is classified in three types: (1) Inner cells, located inside the grid, have six neighbors cells and are subject to all Earth surface processes of the model. (2) Edge cells, located on the edge of the grid, can receive fluvial input of sediment and water external of the grid and are also subject to all Earth surface processes. (3) Sink cells, located on the edge of the grid and are defined as cells whose height value does not vary over time and all the received water and sediment discharge is removed from the model. These cells are used to control the base level of the model.

Any topography discretized into a hexagonal grid can be inputted in the model as the initial topography, in a way that the height value of the cells represent the average heights in the area of the cell. 


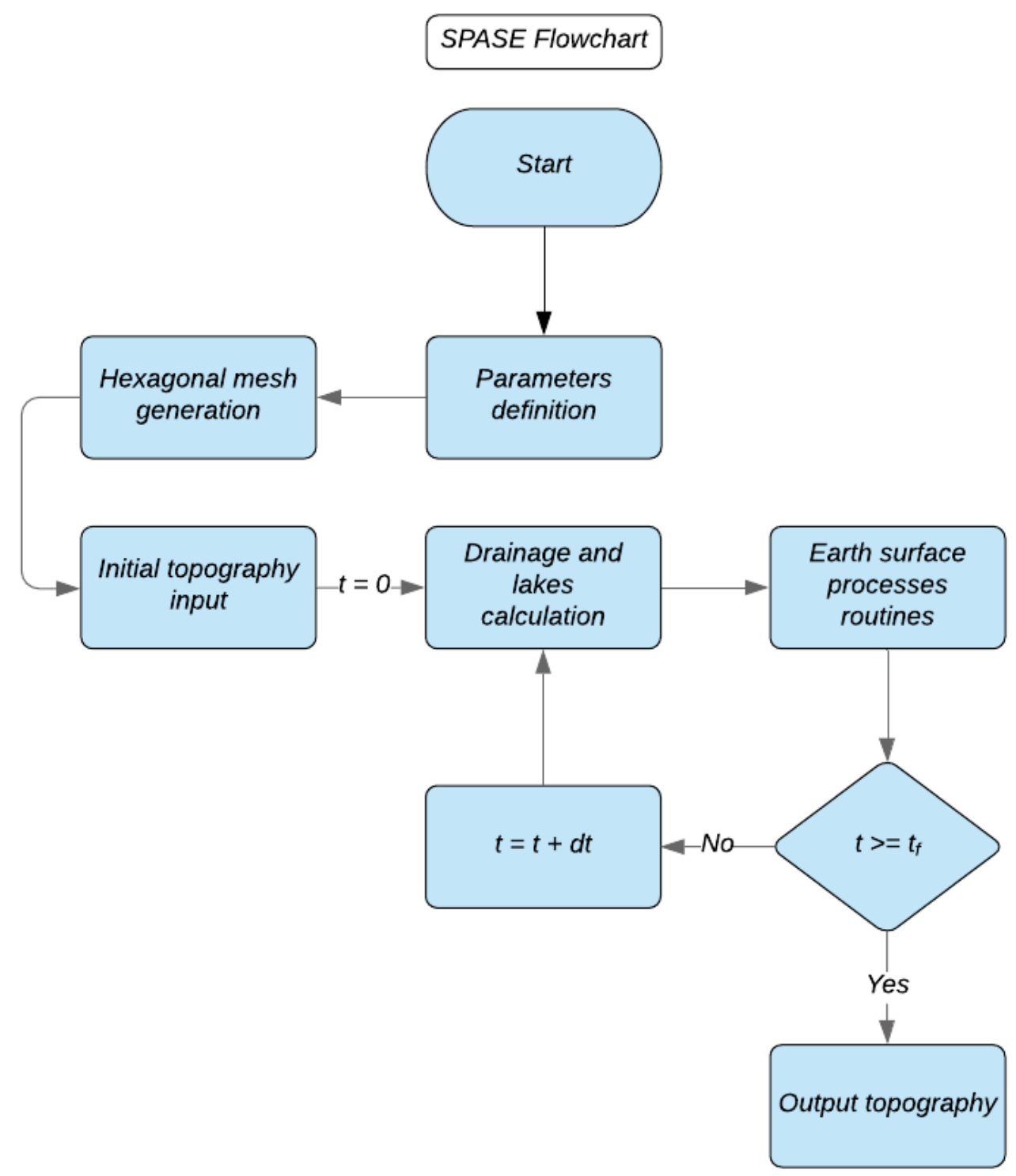

Figure 4.2: Flowchart of SPASE. The time is counted by the variable $t$, the time step is defined by $d t$ and the total time of modelling is $t_{f}$.

\subsection{Earth surface drainage and lakes}

In this model, subsurface water penetration is not considered, so all externally inputted water volume, including rainwater, in this system necessarily has to exit through the sink cells, ensuring the water volume conservation. The calculation of the Earth surface drainage is similar to the cascade algorithm presented by Braun and Sambridge (1997). Rainfall is considered to be 3000 $\mathrm{mm} /$ year, following the regional average, whereas the runoff coefficient (Effective proportion of rainfall) is set to $50 \%$, according to Guimberteau et al. (2013). 
Since the length of cell sides in the model is larger than the width of the channels that are formed within them, the water flow direction is always defined as the direction to the lowest neighbor. Thus, in all cells the volume of water, due to the rainfall rate and river external water input, is transferred to the lowermost neighbors forming the drainage network (Figure 4.3).

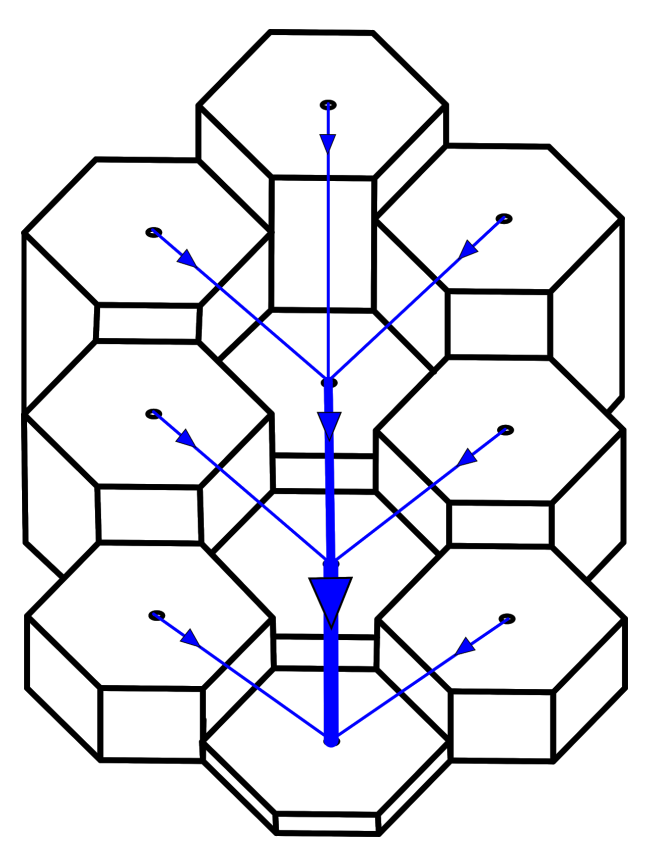

Figure 4.3: Example of a drainage network in hexagonal grid. Blue lines represent the drainage where thickness is relative to its discharge and the arrows indicate the direction of water flow.

The first step to calculate the drainage is sorting the cells from highest to lowest. After that, the direction of flow in each cell is defined by the location of the lowest neighbor (Figure 4.4). In cases where a given cell does not have a lower neighbor cell, it becomes a local minimum resulting in the formation of a lake. 


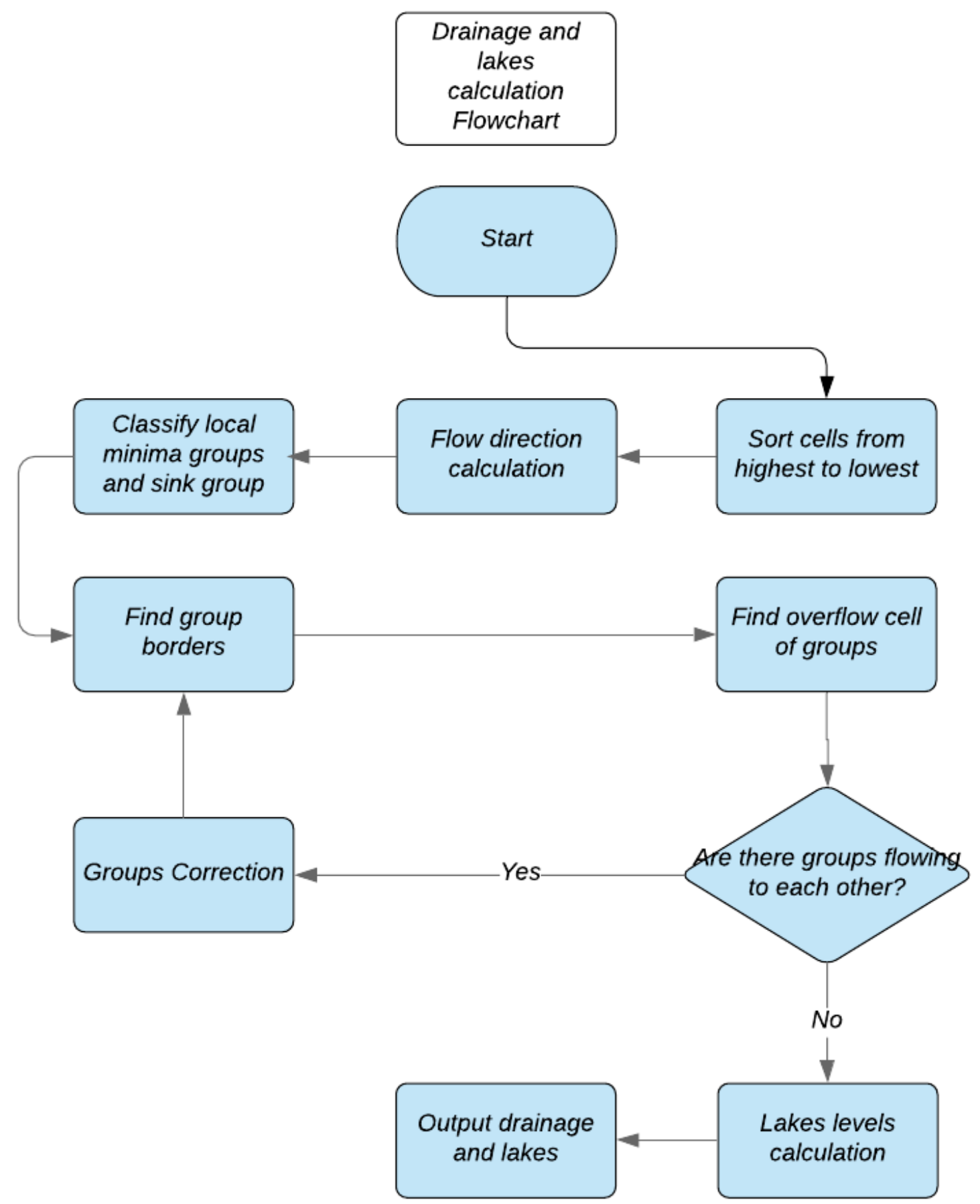

Figure 4.4: Flowchart of drainage and lakes calculation.

During the flow direction calculation process, local minimum and sink cells are flagged. After that, each cell in the grid is classified as belonging to a group of cells flowing to the same local minimum or to the same sink cell (sink group). In each group, every cell that has a neighbor not belonging to the group is later classified as a group border cell. 
Lakes formed in groups of local minimum accumulate water until they reach the necessary height to overflow to a lower neighbor cell, which is named overflow cell. Therefore, the overflow cell will always belong to a neighbour group, with the exception of sink groups where its overflow cell is the sink cell itself. To define the overflow cell, all border cells of a group with local minimum are sorted from lowest to highest and their heights are placed in an array $\left(B_{\text {group }}\right)$. For each cell in the array $B_{\text {group }}$, the height of its lowest neighbor of an external group is stored in an array $\left(S_{\text {neigh }}\right)$. The overflow cell is therefore defined by the following algorithm:

$$
N=0
$$

Flag $=0$

$$
\text { Smaller }=S_{\text {neigh }}[N]
$$

while Flag == 0 :

$$
\begin{aligned}
& \text { if Smaller }>S_{\text {neigh }}[N] \text { : } \\
& \text { Smaller }=S_{\text {neigh }}[N] \\
& \text { if } \boldsymbol{S}_{\text {neigh }}[N]<=B_{\text {group }}[N+1] \text { and } S_{\text {neigh }}[N]<=\text { Smaller: } \\
& \text { Flag }=1 \\
& \text { The address of } \mathbf{S}_{\text {neigh }}[\mathbf{N}] \text { is the overflow cell of the group } \\
& \text { continue } \\
& \text { if } \boldsymbol{S}_{\text {neigh }}[N]>\text { Smaller and Smaller }<=B_{\text {group }}[N+1] \text { : } \\
& \text { Flag }=1 \\
& N=N+1 \\
& \text { if } \boldsymbol{N}>\boldsymbol{N}_{\text {total }} \text { : } \quad \# N_{\text {total }} \text { is the total number of border cells }
\end{aligned}
$$

Flag $=1$

The overflow cell of the group is the address of Smaller continue

After this routine, the drainage among groups is calculated. To avoid cases of groups flowing to each other loopwise, therefore trapping the water flow, a routine of groups correction is called so that these groups are merged to generate a 
'supergroup'. This 'supergroup' is treated as a group and undergoes the same process of finding border cells and overflow cells described above. This step is repeated until all groups are connected to a sink group (Figure 4.4).

With the drainage and all the overflow cells calculated, lake cells are defined as cells in a group lower than the lake height of the same group. The lake height is defined as: (i) the height of the overflow cell, where the neighbor border cells of the overflow cell are lower than the overflow cell itself, or (ii) the height of the lower border cell, neighbor of the overflow cell, where the neighbor border cells of the overflow cell are higher than the overflow cell itself. The depth of the lake in a lake cell is defined by the difference between the cell height and the lake height.

The discharge in each cell is calculated after all the flow directions and the lake cells are defined. When the flow direction leads to a lake cell, all its water discharge is transferred to its overflow cell and the sediment discharge is deposited in the first lake cell.

\subsection{Formulation of the Earth surface processes in the hexagonal grid}

This section describes how depositional and erosional processes operate in the formation of terraces and floodplains in the model. Considering how these processes occur within a cell, new geometrical parameters inside the cells are introduced.

Since the channel width that passes through a cell cannot be greater than the cell side length, it is intuitive to accept that the channel area $\left(A_{\text {channel }}\right)$ is always smaller or equal to the total cell area $\left(A_{\text {hex }}\right)$. Considering an incision case inside a cell, the channel will only erode $A_{\text {channel }}$ and a terrace will be formed within the cell, where the area of terrace $\left(A_{\text {terrace }}\right)$ is the difference between $A_{\text {hex }}$ and $A_{\text {channel. }}$ Additionally, lateral erosion process inside the cell can occur after an incision, implying the formation of a floodplain area $\left(A_{\text {floodplain }}\right)$, which is larger than or equal to $A_{\text {channel. }}$. There are two heights associated with each of these areas, the terrace height $\left(h_{\text {terrace }}\right)$ and the channel height $\left(h_{\text {channel }}\right)$ which is also the floodplain height and is used to define flow direction. Table 4.3 shows the geometric variables used for surface process calculations in each cell. 
Table 4.3: Geometrical parameters of a cell to calculate the Earth surface processes.

\begin{tabular}{|l|l|}
\hline$A_{\text {hex }}$ & Area of a hexagonal cell \\
\hline$A_{\text {channel }}$ & Area of channel \\
\hline$A_{\text {terrace }}$ & Area of terrace \\
\hline$A_{\text {floodplain }}$ & Area of floodplain $\left(>=A_{\text {channel }}\right)$ \\
\hline$h_{\text {channel }}$ & Height of channel and floodplain \\
\hline$h_{\text {terrace }}$ & Height of terrace \\
\hline$L_{\text {cell }}$ & $\begin{array}{l}\text { Distance between the center of two } \\
\text { regular hexagonal cells }\end{array}$ \\
\hline
\end{tabular}

Through empirical data relating discharge to channel width in Amazonia obtained at Brazilian Water Agency (A.N.A.), with an exponential adjusted equation, it is possible to infer the width of a channel given its discharge (Figure 4.5). Assuming that the channel in a cell is straight, $A_{\text {channel }}$ is calculated as the product of the width of the channel in the cell by the distance between the center of two cells $\left(L_{\text {cell }}\right)$.

The order of the cells for the calculation of discharge and Earth surface processes is given by the sorting of values of $h_{\text {channel, }}$, from the highest to the lowest. Following the order, the volume of sedimentary input $\left(q_{\text {sed }}\right)$ is calculated for each cell. Where $q_{\text {sed }}\left[L^{3}\right]$ is the sum of external input of sediment from cells located above or from outside of the grid and the volume of sediment resulting from lateral erosion of the cell itself. Given the available information in the cell (discharge, sediment input and slope), occurrence of erosion, deposition and transport processes in each cell is calculated using equation 4.2. After that stage, the sediment flux out of the cell (new $q_{\text {sed }}$ ) also considers the volume of sediment eroded from or deposited on the channel bottom. After this process is applied in all cells, the Earth surface processes routines stage ends (Figure 4.2). 


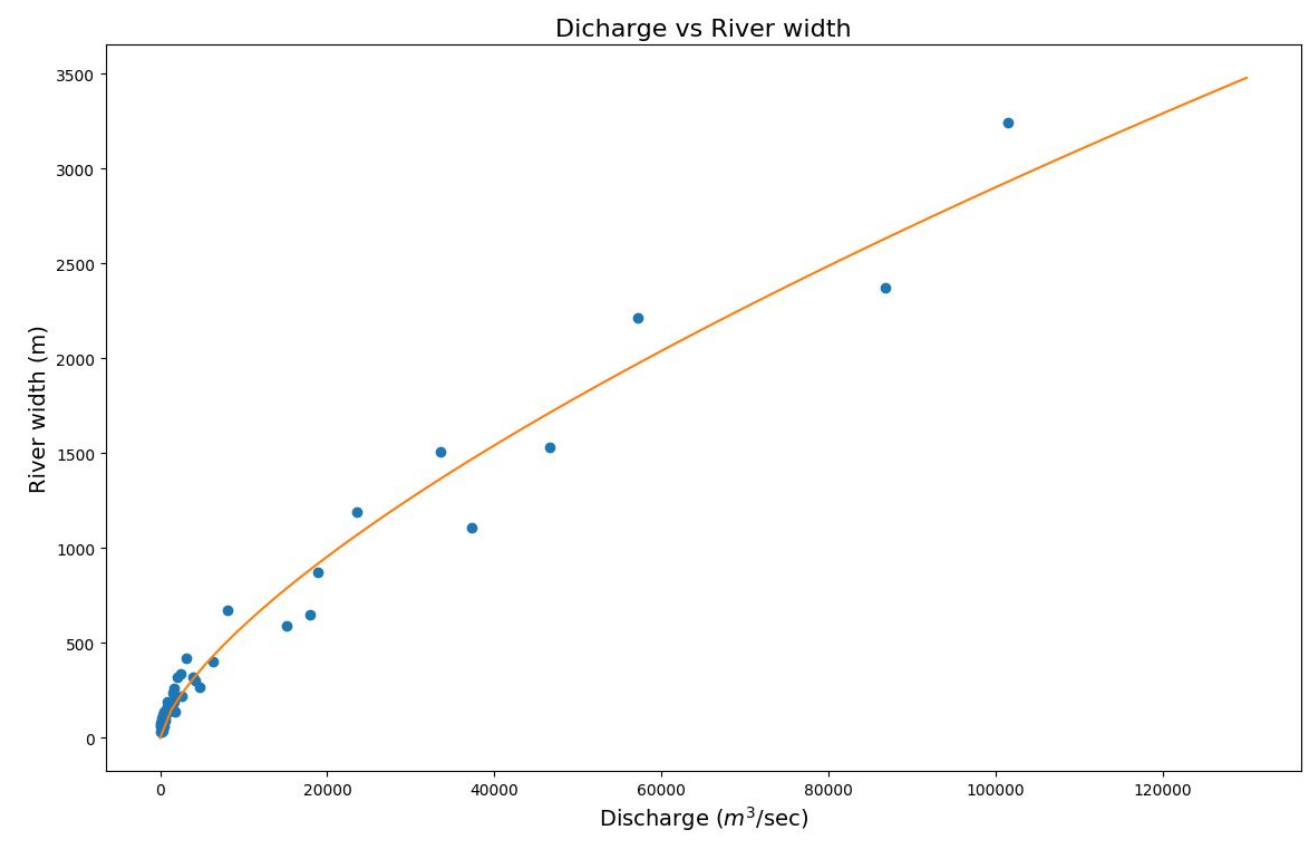

Figure 4.5: Empirical relation between water discharge and river width in Amazonia. Blue dots are the empirical data from 57 data points in 24 amazonian rivers, obtained from Brazilian Water Agency (A.N.A.). Orange line is the exponential curve fitted to the data.

\subsubsection{Discretization of lateral erosion process}

This section describes how the lateral erosion process occurs in each cell.

If $h_{\text {channel }}<h_{\text {terrace }}$ in a cell, lateral erosion takes place and the volume of sediment eroded, $B$, is calculated by the integrated form of equation 4.3:

$$
B=a_{l e}\left(\left[h_{\text {terrace }}-h_{\text {channel }}\right]+h_{\text {depth }}\right)
$$

Where for simplicity $h_{\text {depth }}$ is defined as the width of channel divided per 100 and $a_{l e}$ is the discretized form of equation 4.4 , defined by:

$$
a_{l e}=r \frac{q_{e q b}}{L_{l e}} \frac{A_{\text {channel }}}{A_{\text {floodplain }}}
$$


The random fraction coefficient $(r)$ is a random value between 0 and 1 introduced in the equation with the intention to take into account the complex effects caused by hydrodynamics that eventually causes the lateral erosion at greater or lower rates. The introduced ratio between $A_{\text {channel }}$ and $A_{\text {floodplain }}$ quantifies the influence of the presence of floodplain on lateral erosion of terraces inside a cell: the lesser the ratio $\left(A_{\text {floodplain }}>A_{\text {channel }}\right)$, the lesser is the laterally eroded area of the terrace, causing a decrease in the volume of sediment produced in a time step. The maximum volume of sediment that the cell can carry in a timestep $\left(q_{\text {eqb }}\right)$, which is the integrated form of $Q_{\text {eqb }}$, is given by equation 4.1:

$$
q_{\text {eqb }}=K_{f} \Delta t\left(Q_{r}\right)^{m}\left(\frac{h_{i}-h_{j}}{L_{\text {cell }}}\right)^{n}
$$

Where $Q_{r}$ is the water discharge in the cell due to rainfall and external input, $h_{i}$ is the $h_{\text {channel }}$ of the actual cell and $h_{j}$ is the $h_{\text {channel }}$ of the cell to where the discharge will flow. Figure 4.6 shows an example of lateral erosion occuring in a hexagonal grid.

If the whole terrace area is eroded in a cell $\left(A_{\text {terrace }}=0 ; A_{\text {floodplain }}=A_{\text {hex }}\right)$ lateral erosion takes place in its neighbor cells only when the neighbor cells have their $h_{\text {channel }}$ greater than the $h_{\text {channel }}$ of the original cell. The volume of sediment eroded in each neighbor cell is calculated by equation 4.5. In this case, $h_{\text {terrace }}$ is the terrace height of a neighbor cell and $h_{\text {channel }}$ is the channel height in the original cell. The total volume of laterally eroded sediments (inside a cell + neighbor cells) is added to the $q_{\text {sed }}$ of the original cell. 

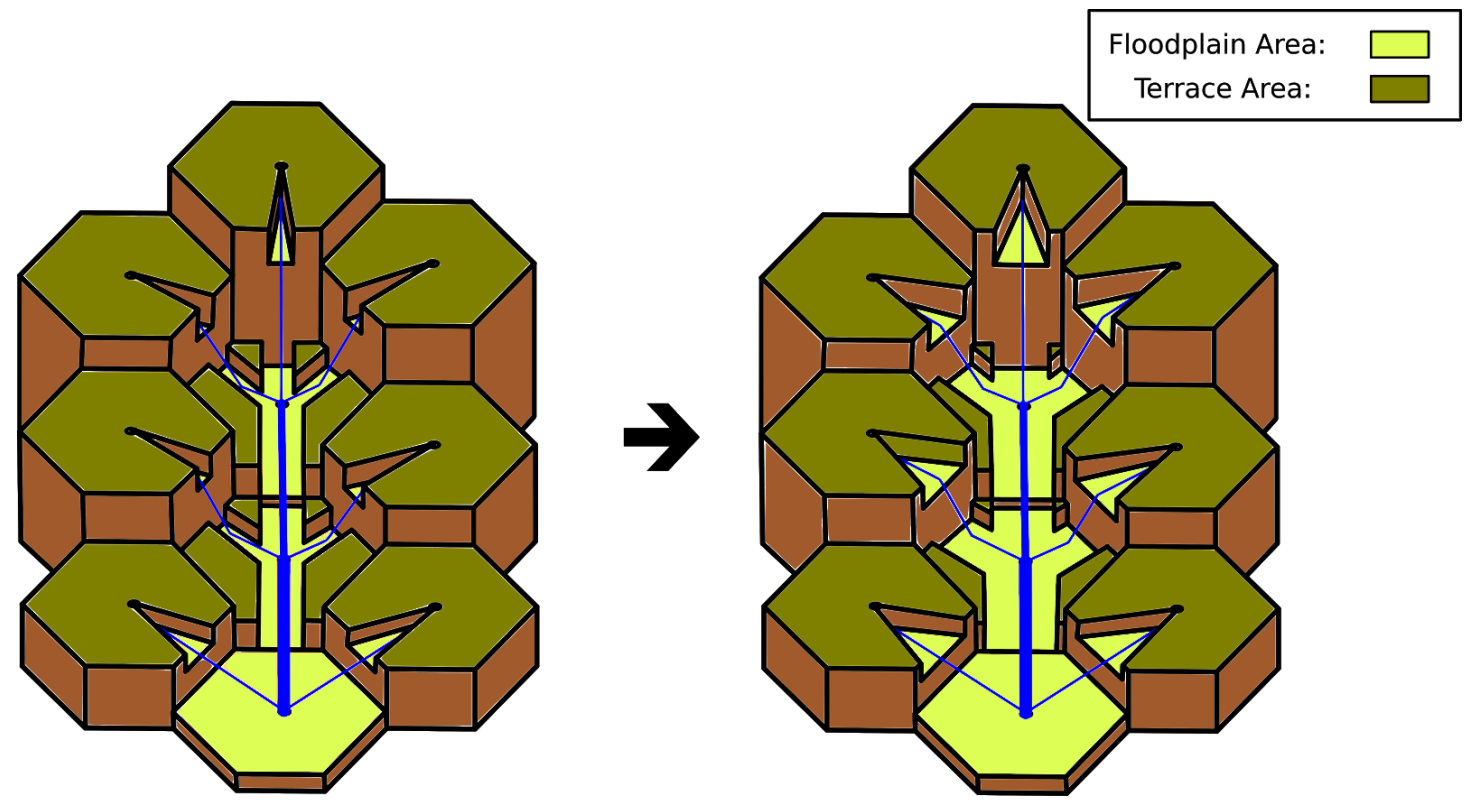

Figure 4.6: Conceptual representation of before-after scenario in a hexagonal grid in a time step of lateral erosion process. Each cell has three geometrical parameters, channel area in blue $\left(A_{\text {channel }}\right)$, floodplain area in light green $\left(A_{\text {floodplain }}\right)$ and terrace area in dark green $\left(A_{\text {terrace }}\right)$. After the time step, the floodplain area in each cell increases due to lateral erosion.

\subsubsection{Fluvial processes of transport, deposition and bed erosion}

The difference between $q_{\text {sed }}$ and the $q_{\text {eqb }}$ (Equation 4.7) calculated in the cell determines whether a cell undergoes a process of deposition or erosion. If $q_{\text {sed }}>q_{\text {eqb }}$, deposition takes place and equation 4.2 assumes the following discrete form:

$$
\Delta h_{\text {channel }}=\frac{q_{\text {sed }}-q_{\text {eqb }}}{A_{\text {floodplain }}}
$$

Where $\Delta h_{\text {channel }}$ is the value that will be added to $h_{\text {channel }}$ of the cell. The length scale property of the material in suspension $\left(L_{s}\right)$ in the river is considered as equal to 1 , not appearing in this equation. If $h_{\text {channel }}+\Delta h_{\text {channel }}$ is greater than the $h_{\text {terrace }}$ of the cell, the following equation takes place:

$$
\Delta h_{\text {terrace }}=\frac{\left[q_{\text {sed }}-q_{\text {eqb }}-A_{\text {floodplain }} *\left(h_{\text {terrace }}-h_{\text {channel }}\right)\right]}{A_{\text {hex }}}
$$


Where $\Delta h_{\text {terrace }}$ is the height that will be added to the initial $h_{\text {terrace }}$ of the cell. After $\Delta h_{\text {terrace }}$ is calculated, the variables are updated as follows: $h_{\text {terrace }}=h_{\text {terrace }}+$ $\Delta h_{\text {terrace }} ; h_{\text {channel }}=h_{\text {terrace }}+\Delta h_{\text {terrace }} ; A_{\text {floodplain }}=A_{\text {hex }}$. After deposition is calculated in 4.8 or if necessary 4.9 , the volume $q_{\text {eqb }}$ is transferred to the $q_{\text {sed }}$ of the neighbour cell that receives the flow.

If $q_{\text {sed }}<q_{\text {eqb, }}$, bed erosion takes place and equation 4.2 assumes the following discrete form:

$$
\Delta h_{\text {channel }}=\frac{q_{\text {sed }}-q_{\text {eqb }}}{A_{\text {channel }}} \frac{L_{\text {cell }}}{L_{a}}
$$

Where $\Delta h_{\text {channel }}$ is the height that will be subtracted from the initial $h_{\text {channel. }}$. The length scale property of the river bed material $\left(L_{a}\right)$ represents a value of unconsolidated material and is considered to be constant for all cells, since the landscape represents an alluvial environment with recent deposits. The ratio between $L_{\text {cell }}$ and $L_{a}$ needs to be equal or lower than 1. Incision occurs only in the $A_{\text {channel }}$ of the cell and the height of terrace $\left(h_{\text {terrace }}\right)$ is recalculated by the following equation:

$$
h_{\text {terrace }}=\frac{\left(h_{\text {terrace }}-h_{\text {channel }}\right) *\left(A_{\text {hex }}-A_{\text {floodplain }}\right)}{\left(A_{\text {hex }}-A_{\text {channel }}\right)}
$$

Equation 4.11 is applied in order to maintain only one level of terrace in the cell. After $h_{\text {terrace }}$ is calculated, the variables are updated as follows: $A_{\text {floodplain }}=A_{\text {channel }}$; $A_{\text {terrace }}=A_{\text {hex }}-A_{\text {channel. }}$. After this $h_{\text {channel }}$ is updated following equation 4.10 and the volume $Q_{\text {sed }}-\Delta h_{\text {channel }}{ }^{*} A_{\text {channel }}$ is transferred to the neighbor cell that receives the flow. This stage ends after the Earth surface processes routines were applied to all cells. Following the flowchart in Figure 4.2, if a given time $(t)$ in the model isn't the final time $\left(t_{f}\right), t$ is updated with $t+d t$ and the drainage and lakes calculation routines will be called again and run in the updated topography. If $t$ is equal or greater than $t_{f}$ the model stops and the final topography is saved in a file. Files with the topography in predefined time stages may also be saved to study the evolution of the model. The 
total processing time to simulate $10 \mathrm{ky}$ in a grid composed of 10 thousand cells (100 $x 100$ cells), with $d t=0.01 \mathrm{y}$, is 38 hours. 


\section{APPLICATION OF SPASE}

The results of the SPASE model are displayed in maps and elevation profiles of the river. The maps were generated by a code in Python developed to reproduce the visualization of both drainage and topography in the same image, in which each hexagon is a cell that its color shows the height of $h_{\text {terrace. }}$ Lakes are shown as a smooth blue hexagons. Cells are regular hexagons with 4.000 meters of each side and the total number of cells is 10.000 (100 100 cells). Since in the model the rivers are considered to follow straight routes inside the cells, the slope used as a parameter constraint is the floodplain slope, and not the sinuous channel slope.

Unless stated differently, the scenarios presented in the following sections use the values described in Table 5.1.

Table 5.1: Values of the parameters used in most of the tested scenarios described in the following sections.

\begin{tabular}{|c|c|c|c|}
\hline$K_{f}$ & 0.0054 & $L_{a}$ & $10 \mathrm{~km}$ \\
\hline$m$ & 1.54 & $L_{l e}$ & $1 \mathrm{~km}$ \\
\hline$n$ & 1.0 & $\begin{array}{c}\text { Effective rainfall } \\
\text { rate }\end{array}$ & $1500 \mathrm{~mm} \mathrm{y}^{-1}$ \\
\hline $\mathrm{dt}$ & 0.01 years & Cell side size & $4 \mathrm{~km}$ \\
\hline
\end{tabular}

\subsection{Initial scenario}

The inputted initial topography of the model, for the tested scenarios in the next sections, is similar to the modern topography of Amazônia lowlands in the region of confluence between Juruá River and Solimões River (Figure 5.1). This topography presents low-slope $(\sim 6 \mathrm{~cm} / \mathrm{km}$ in the Solimões River floodplain and $\sim 14 \mathrm{~cm} / \mathrm{km}$ in the Juruá River floodplain), lowland valleys bearing floodplains near the larger rivers, and terraces forming elevated interfluves.

The initial scenario displays two main rivers, one entering the grid with a defined water and sediment discharge similar to the Juruá River (Table 4.1), in the 
upper right corner of the map, and one entering the grid with a defined water and sediment discharge similar to the Solimões River (Table 4.1), in the lower right corner of the map. The river similar to the Solimões River is here defined as 'trunk river' and the river similar to Juruá River is defined as 'main tributary'. Sink cells are in the lower left corner locked at an altitude of 140 meters.
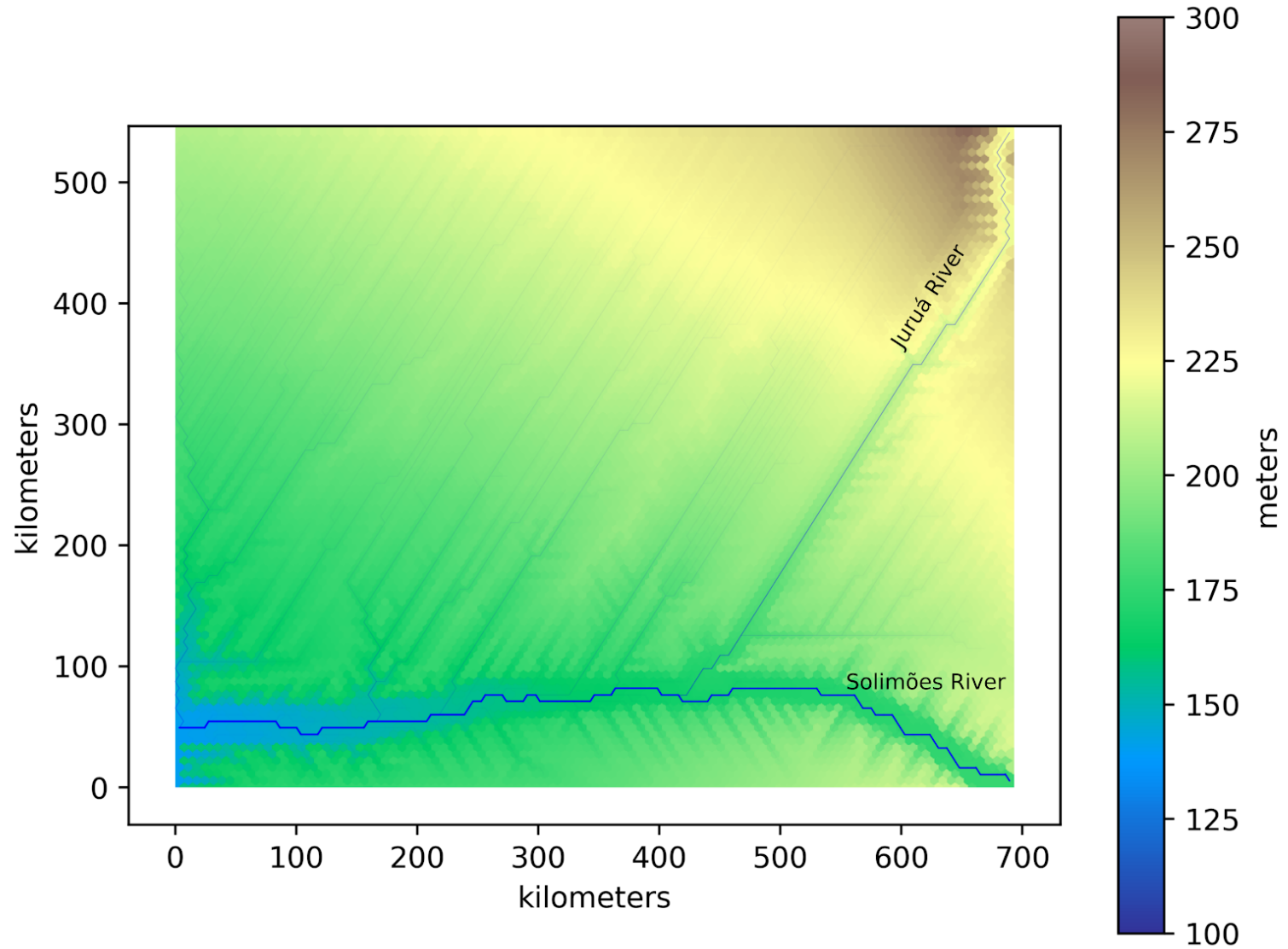

Figure 5.1: Initial scenario for this study case. Blue lines represent channels, where the thickness is proportional to the discharge. In the upper right corner, a river with discharge similar to the Jurua River $\left(4.750 \mathrm{~m}^{3} / \mathrm{s}\right)$ is inputted, and in the lower right corner a river with discharge similar to the Solimões River $\left(54.940 \mathrm{~m}^{3} / \mathrm{s}\right)$ is inputted. Sink cells are in the lower left corner locked at an altitude of 140 meters. Cells are regular hexagons with 4.000 meters of side and the total number of cells is 10 thousand. The values of height are to an arbitrary referential and not to the modern sea level. In comparison with the actual topography and drainage of the region of confluence between Juruá and Solimões River, the north points down in this representation.

An elevation profile of the actual Juruá River was obtained, from the digital elevation model in Google Earth (Figure 5.2), to be used as comparison with the 
resulting elevation profiles for scenarios tested in next sections. The elevation profile of initial topography (shown in Figure 5.3) is compared with the profile of modern Juruá River.

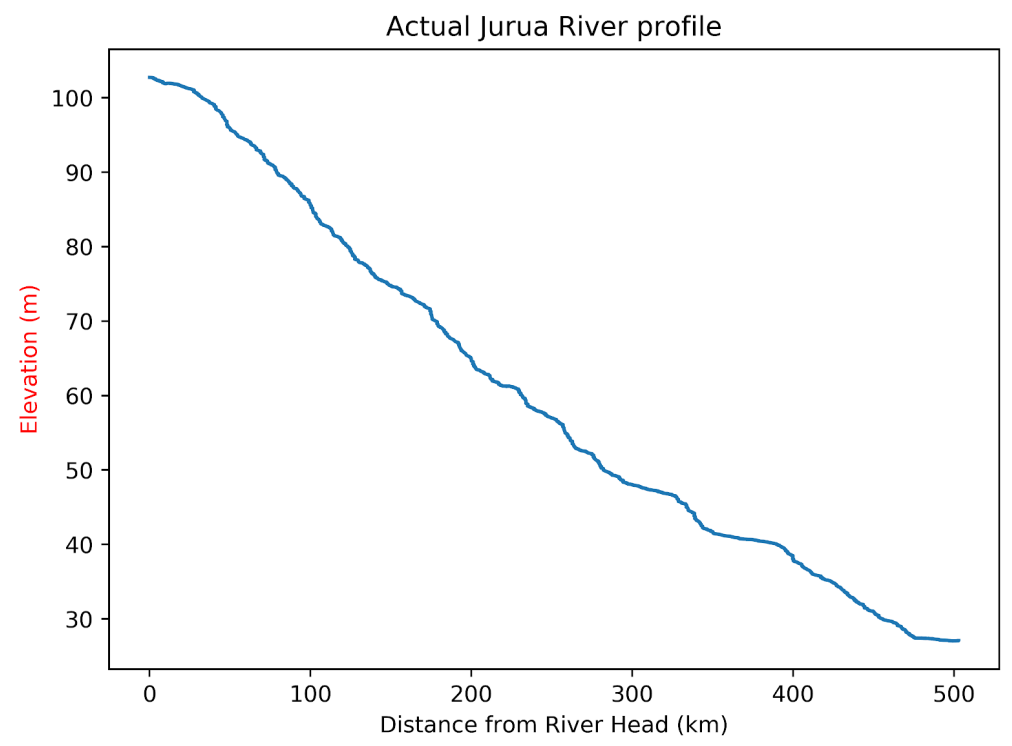

Figure 5.2: Elevation profile of actual Jurua River in the trench shown in the red square in Figure 3.1, obtained in Google Earth after a low-pass filter. Mean slope $\sim 14 \mathrm{~cm} / \mathrm{km}$.

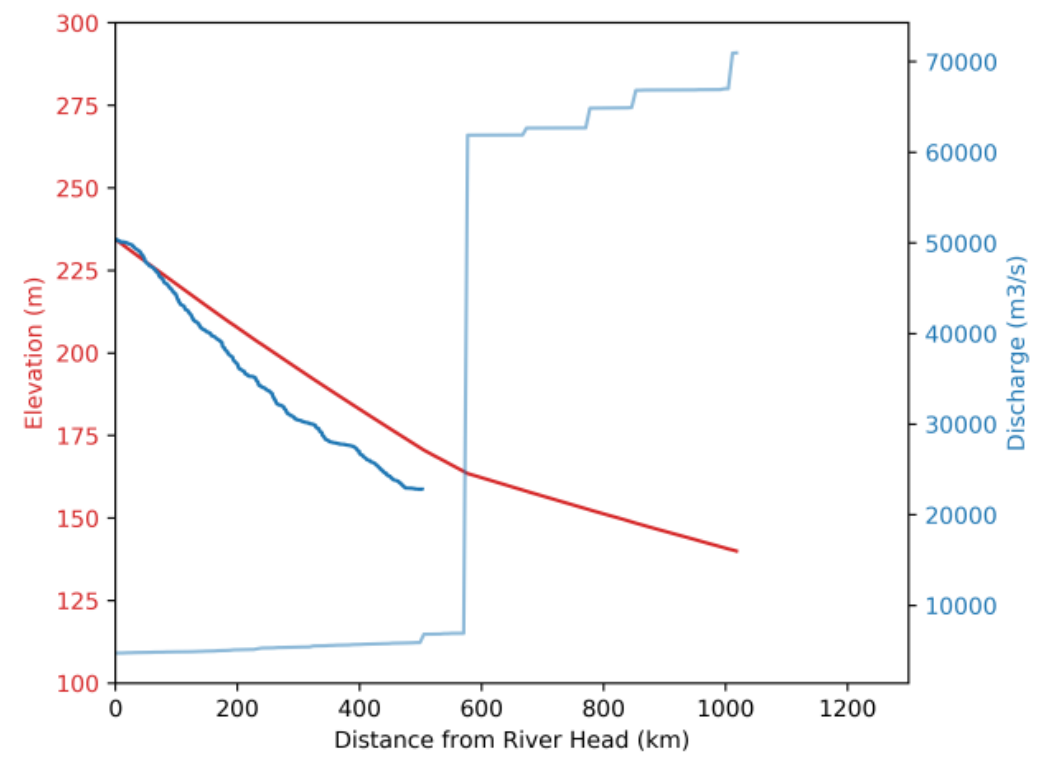

Figure 5.3: Elevation profile of the main tributary in the initial topography compared to the elevation profile of the modern Juruá River (Dark blue line). The discharge of the main tributary in the model (Light blue line) shows the confluence with the trunk river when increases from $\sim 6000 \mathrm{~m}^{3} \mathrm{~s}^{-1}$ to $\sim 60000 \mathrm{~m}^{3} \mathrm{~s}^{-1}$. 


\subsection{The effects of different lateral erosion parameters and base level}

drop

The volume of sediment laterally eroded from the channel margin at each time step, expressed by equation 4.6, is inversely proportional to the constant of lateral erosion length scale $\left(L_{l e}\right)$. In this section, different values for $L_{l e}$ are tested $\left(L_{l e}\right.$ $=10^{1}, 10^{2}, 10^{3}$ and $10^{4} \mathrm{~m}$ ) in an incisive (base level drop) scenario to discuss the responses of the numerical model. To create an incisive scenario, the initial topography, shown in Section 5.1, the base level (height of the sink cells) is lowered $40 \mathrm{~m}$ (from 140 to 100 meters).

Figures 5.4 and 5.5 show the comparison of the topography and drainage evolution at $t=100,1000$ and 5000 years. For $t=100$ years the following scenarios are developed with the different values of $L_{l e}$ : incision and valley opening take place with $L_{l e}=10^{1}$ and $L_{l e}=10^{2} \mathrm{~m}$, with a greater valley opening with $L_{l e}=10^{1} \mathrm{~m}$ (Figure 5.4); valley opening cannot be seen yet in the scenarios with $L_{l e}=10^{3}$ and $L_{l e}=10^{4}$ $\mathrm{m}$, where lateral erosion occurs at low rates and bed erosion is intensified (Figure 5.5). For $t=1000$ and 5000 years the opening of the valley is observed in all $L_{l e}$ scenarios, in a way that the width of these valleys decreases as the value of $L_{l e}$ increases, as expected.

Figure 5.6 shows the comparison of the topography and drainage evolution at $t=10 \mathrm{ky}$ for $L_{l e}=10^{1}, 10^{2}, 10^{3}$ and $10^{4} \mathrm{~m}$. In all cases of $L_{l e}$, the width of the opened floodplains of the trunk river and the main tributary are different: the trunk river always produces a wider floodplain than the main tributary, which may be due to the difference of discharge and therefore the capacity of sediment transport. For comparison, the modern width of the floodplains of the Jurua and Solimões rivers next to the confluence are $\sim 25$ and $50 \mathrm{~km}$ respectively. Since the floodplain widens only at times when the channel is at the edge of the valley, it is intuitive to conclude that the valley widening rate decreases as its width increases.

Considering that the events of incision in this region happened about $50 \mathrm{ka}$ (Pupim et al., 2019), the $L_{l e}$ that best fits the modern scenario of valley width is the one with $L_{l e}=10^{3} \mathrm{~m}$, where at $\mathrm{t}=10 \mathrm{ky}$ the valley width in the trunk river and its main 
tributary are $19.5 \mathrm{~km}$ and $7.1 \mathrm{~km}$ respectively (Figure 5.6). Therefore, the value of $L_{l e}$ used in the following sections $L_{l e}$ is $10^{3} \mathrm{~m}$.
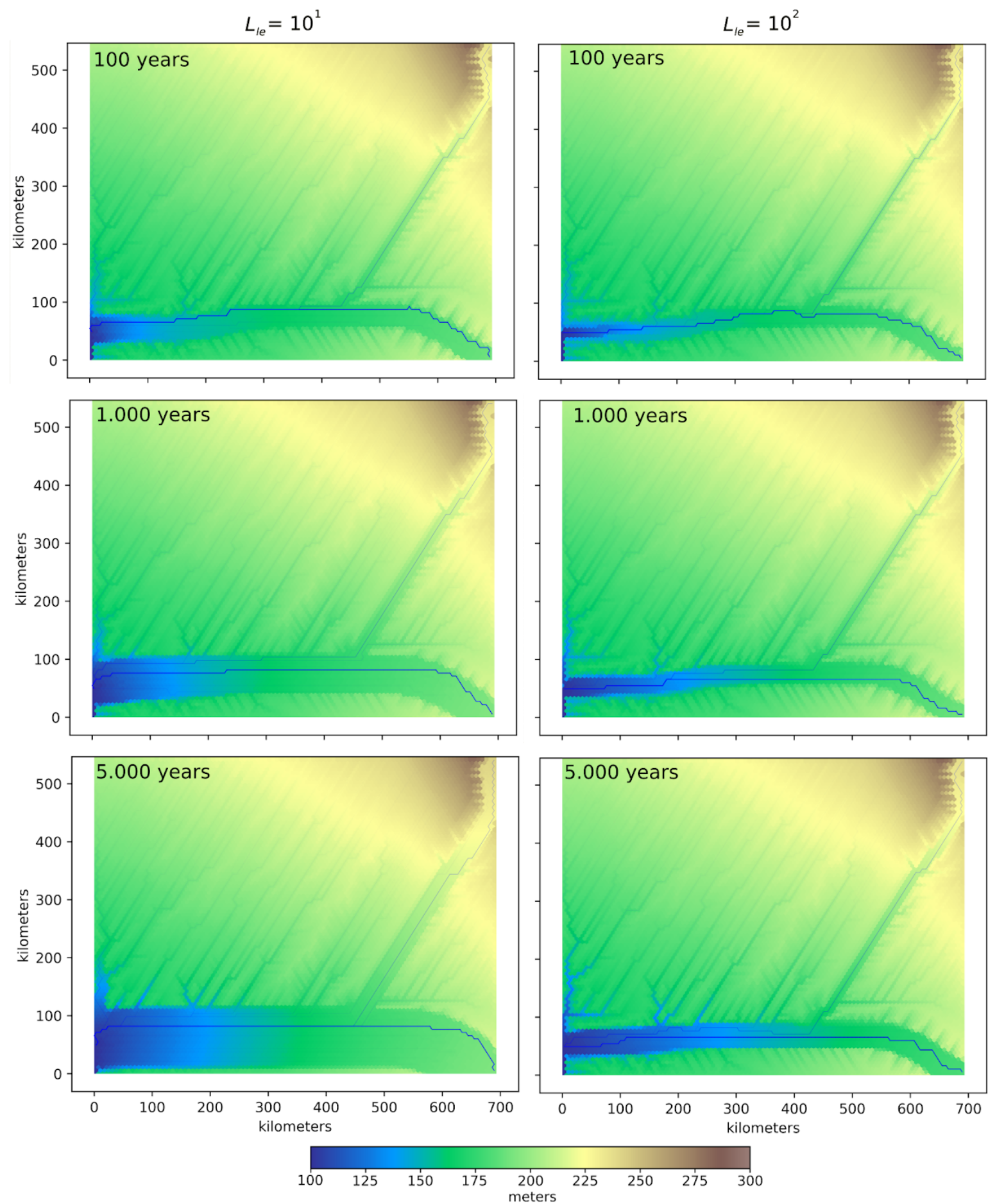

Figure 5.4: Topography $\left(h_{\text {terrace }}\right)$ and drainage evolution in an incisive scenario for $L_{l e}=10^{1}$ and $10^{2} \mathrm{~m}$. With $\mathrm{t}=100,1000$ and 5000 years. The development of the valleys from the lower left corners of the images appears in blue tones with lower elevation. 

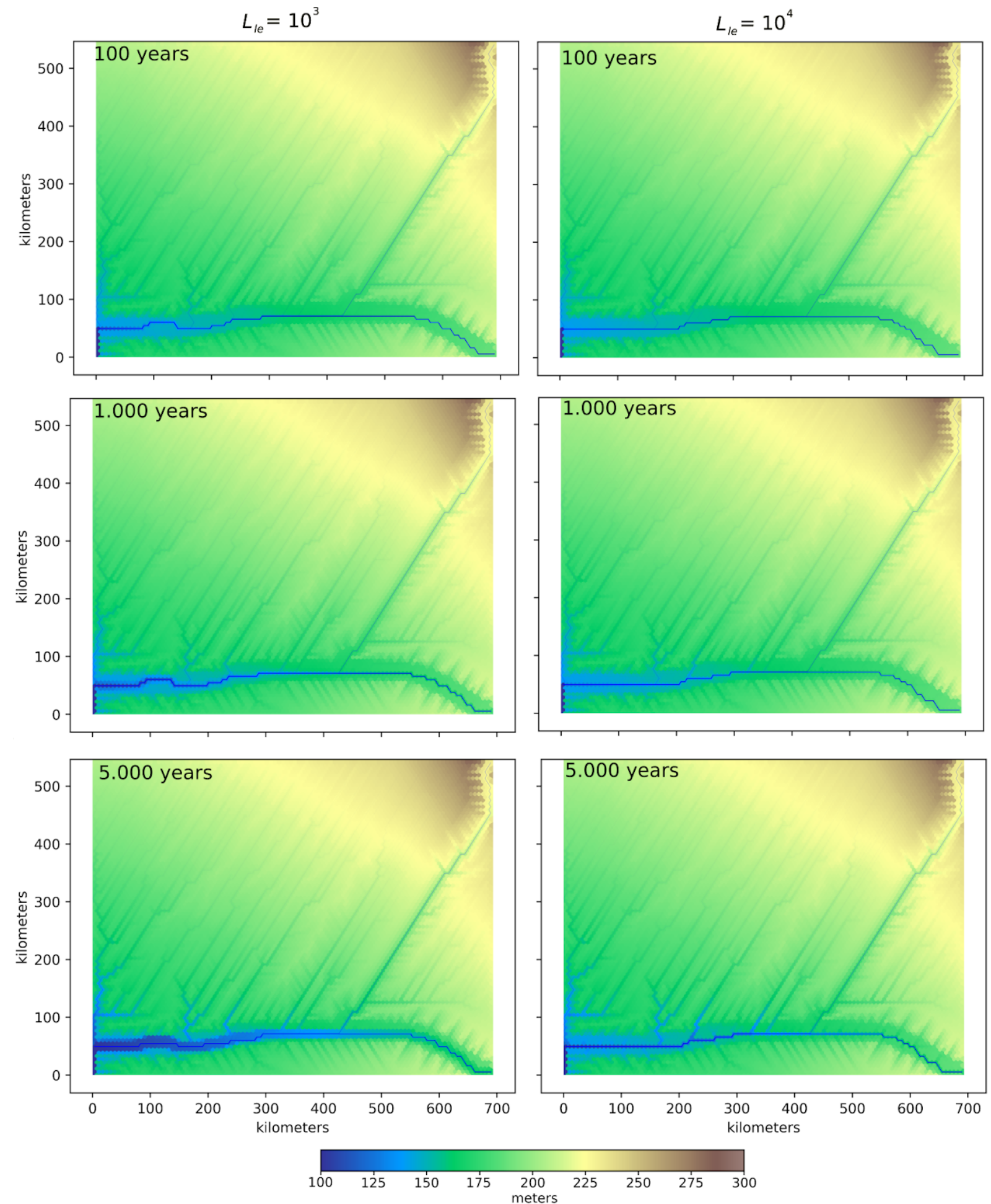

Figure 5.5: Topography $\left(h_{\text {terrace }}\right)$ and drainage evolution in an incisive scenario for $L_{l e}=10^{3}$ and $10^{4} \mathrm{~m}$. With $\mathrm{t}=100,1000$ and 5000 years. From the lower left corners of the images, the development of the valleys appears in blue tones with lower elevation. 

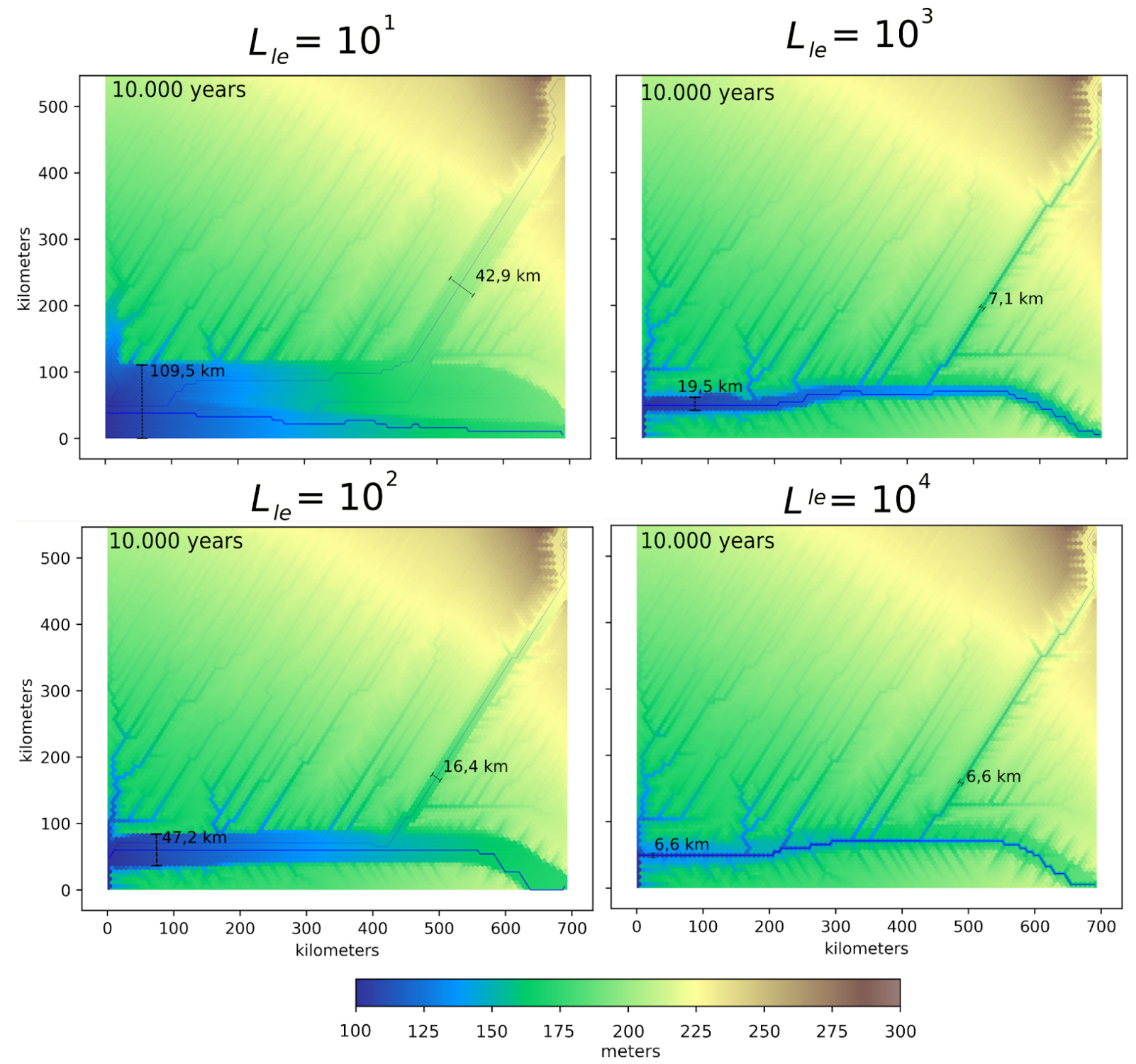

Figure 5.6: Topography and drainage response at $\mathrm{t}=10 \mathrm{ky}$ in an incisive scenario for $L_{l e}=$ $10^{1}, 10^{2}, 10^{3}$ and $10^{4} \mathrm{~m}$. The width of the developed valleys in each resulting topography scenario is shown. Note that wider valleys develop with larger $L_{l e}$.

Comparison of the initial elevation profile $(t=0)$ with the final elevation profiles ( $\mathrm{t}=10 \mathrm{ky}$ ) (Figure 5.7) shows that the incision has different amplitudes for different values of $L_{l e}$. For $L_{l e}=10^{1}$ and $L_{l e}=10^{2} \mathrm{~m}$, the elevation in the river head increased, showing deposition of sediments even in an incisional scenario: $L_{l e}=10^{1}$ $\mathrm{m}$ displays deposition until $\sim 600 \mathrm{~km}$ in distance from the river head, whereas $L_{l e}=$ $10^{2} \mathrm{~m}$ until $250 \mathrm{~km}$. This occurs due to the amount of sediment produced by lateral erosion being too large for the river to carry at the initial slope, so the deposition 
occurs until a higher slope of equilibrium is reached. The comparison of the initial profile with the final profiles of $L_{l e}=10^{3} \mathrm{~m}$ and $L_{l e}=10^{4} \mathrm{~m}$ shows that the entire elevation of all the profiles decreased: the river head elevation decreased $\sim 8 \mathrm{~m}$ for $L_{l e}=10^{3} \mathrm{~m}$ and $\sim 18 \mathrm{~m}$ for $L_{l e}=10^{4} \mathrm{~m}$.

It should be noted that, in an incisive scenario, smaller tributaries had their elevation decrease contained by lateral erosion, because when bed erosion caused by incision happens, in the $A_{\text {channel }}$ of a cell, the difference between $h_{\text {terrace }}$ and $h_{\text {channel }}$ increases and the volume of sediment laterally eroded also increases. In this case, channels with low discharges $\left(Q_{\text {sed }}\right)$ reach easily the value of the carrying capacity $\left(q_{\text {eqb }}\right)$, stopping the bed erosion.

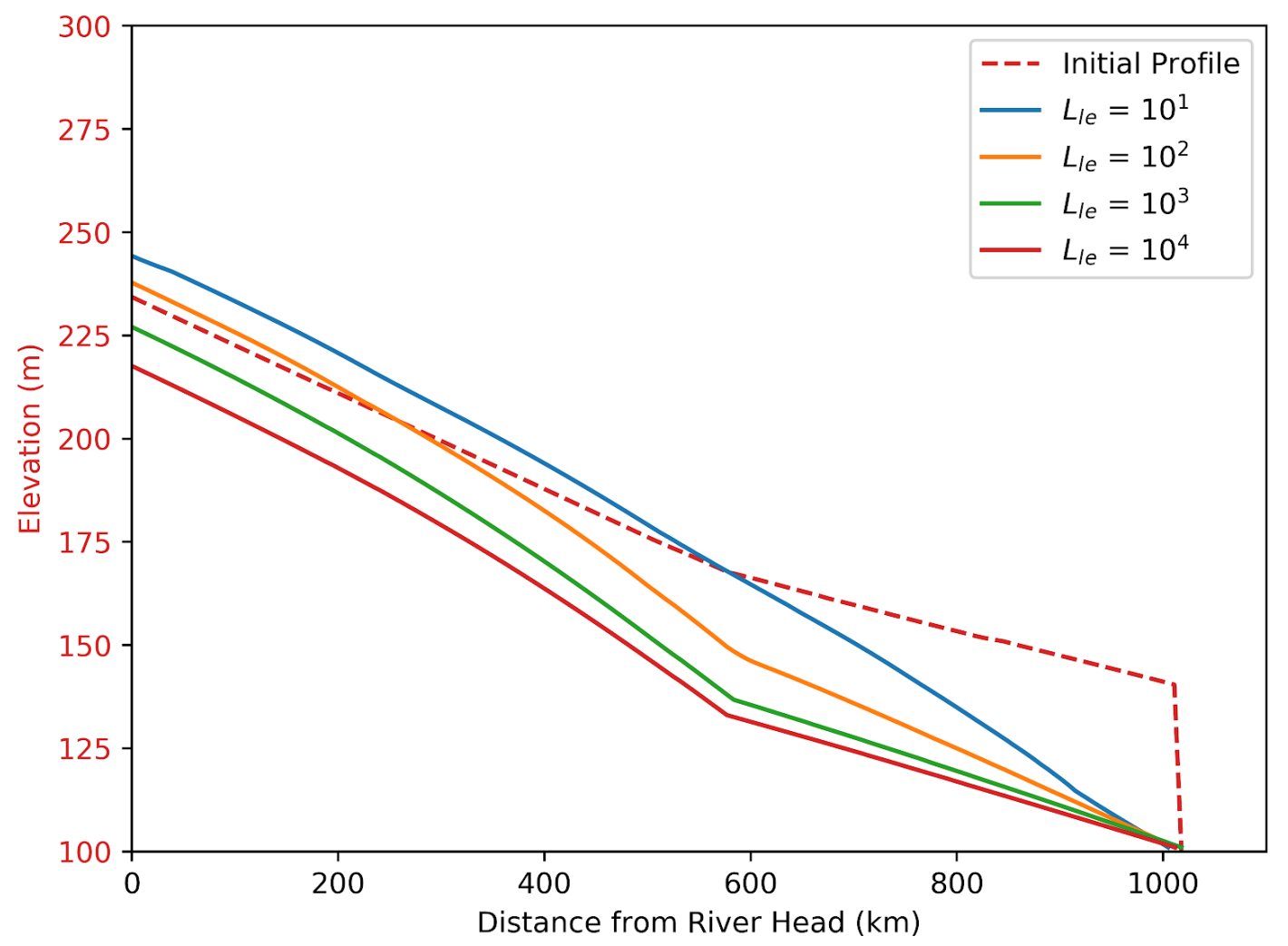

Figure 5.7: Elevation profiles $\left(h_{\text {channel }}\right)$ of the main tributary resulted with $L_{l e}=10^{1}, 10^{2}, 10^{3}$ and $10^{4} \mathrm{~m}$, at $\mathrm{t}=10 \mathrm{ka}$, in comparison with initial elevation profile. By increasing $L_{l}$ the response of the elevation profile changes to a more incisive scenario, due to the decrease of the sediment volume laterally eroded by the channels.

The results of this section highlight the influence of the lateral erosion process in the evolution of the river profiles and landscape in alluvial systems. Without lateral erosion there would be no valley opening and incisive scenarios would 
have river profiles with lower elevations. This also highlights the importance of taking into account the lateral erosion process in numerical models that aims to study landscape evolution in alluvial systems.

\subsection{The effects of variation in river sediment input}

In this section, for the main tributary, different values of sediment input were tested in SPASE to evaluate the changes in elevation profile of the river as a function of the ratio between water and sediment input. Modern river sediment and water input values are shown in Table 4.1 and the tested values of sediment discharge input for the main tributary are $0.15 \mathrm{~m}^{3} \mathrm{~s}^{-1}, 0.25 \mathrm{~m}^{3} \mathrm{~s}^{-1}, 0.37 \mathrm{~m}^{3} \mathrm{~s}^{-1}, 0.47 \mathrm{~m}^{3} \mathrm{~s}^{-1}, 0.63 \mathrm{~m}^{3}$ $\mathrm{s}^{-1}$ and $0.94 \mathrm{~m}^{3} \mathrm{~s}^{-1}$.

The resulting profiles show that the slope of the main tributary increases with the increase of sediment input (Figure 5.8) and the result with input of $0.47 \mathrm{~m}^{3} \mathrm{~s}^{-1}$ is the best fit with the modern Juruá River elevation profile. This result is not incompatible with the measured suspended sediment flux for Juruá River of $0.35 \mathrm{~m}^{3}$ $\mathrm{s}^{-1}$ obtained by Filizola and Guyot (2009), considering both the inherent uncertainty of extrapolating scarce sediment flux data and the presence of unmeasured bedload flux. 

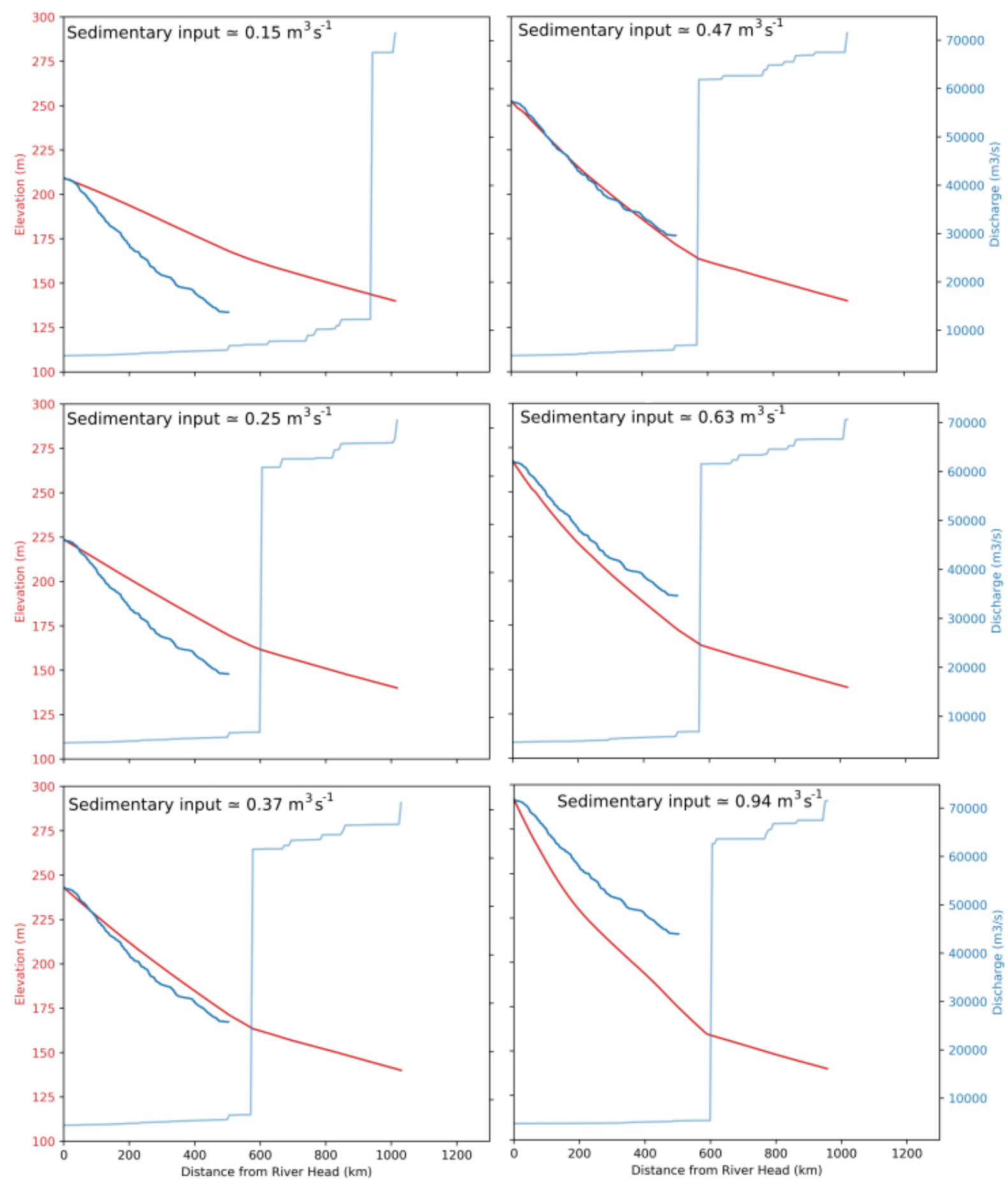

Figure 5.8: Elevation profiles of the main tributary from SPASE (Red line) with different values of sediment input, for $\mathrm{t}=10 \mathrm{ky}$ and elevation value of $h_{\text {channel }}$ in each cell, in comparison with elevation profile of actual Juruá River (Dark blue line). The water discharge of the main tributary in the model is represented by the light blue line. The best fit line adjustment of the elevation profile is to the value of $0.47 \mathrm{~m}^{3} \mathrm{~s}^{-1}$ to the sedimentary input. 


\subsection{Climate change effects}

One of the objectives of this work is to test the possible role of climate changes in the evolution of the Amazônia alluvial landscape. In SPASE model, climatic changes can be reproduced by testing different values of rainfall as well as water discharges from the model grid boundaries. As discussed in Section 5.3, the input ratio between discharge and sediment volume flux has a large influence on the elevation profile of a channel. This makes it difficult to propose sediment discharge input values from the model grid boundaries in scenarios with different water discharges than the current one without affecting greatly all river profiles. To isolate this issue, scenarios were tested in which only the rainfall values within the grid were modified to evaluate the effects of climate change in channel elevation profiles and topography during $10 \mathrm{ky}$.

As defined in Section 4.3, the rainfall for testing variation in all other parameters was $3000 \mathrm{~mm} \mathrm{y}^{-1}$ with the runoff coefficient of $50 \%$, which implies a constant rainfall in the grid of the model of $1500 \mathrm{~mm} \mathrm{y}^{-1}$ (as evapotranspiration and loss to groundwater reservoirs are not modeled). To evaluate the effects of climate change, tested scenarios used the values of 100, 500, 1000, 1500, 2000 and 3000 $\mathrm{mm} \mathrm{y}^{-1}$ of rainfall. The sediment flux input for the main tributary is $0.47 \mathrm{~m}^{3} \mathrm{~s}^{-1}$ and for trunk river is $6.5 \mathrm{~m}^{3} \mathrm{~s}^{-1}$.

The resulting elevation profiles of the main tributary for the tested scenarios show a relation between rainfall and depositional/erosional processes (Figure 5.9). The resulting profiles for rainfall of 2000 and $3000 \mathrm{~mm} \mathrm{y}^{-1}$ show incision in comparison with the initial profile. And by decreasing rainfall the profiles increases the values of elevation, showing a depositional process for the profiles with rainfall of 100, 500, 1000 and $1500 \mathrm{~mm} \mathrm{y}^{-1}$. The increase of rainfall increases the incision due the increase of discharge and, consequently, the increase of $Q_{\text {eqb }}$ along the river, as well as the decrease of rainfall that causes deposition due the decrease of $Q_{\text {eqb }}$. 


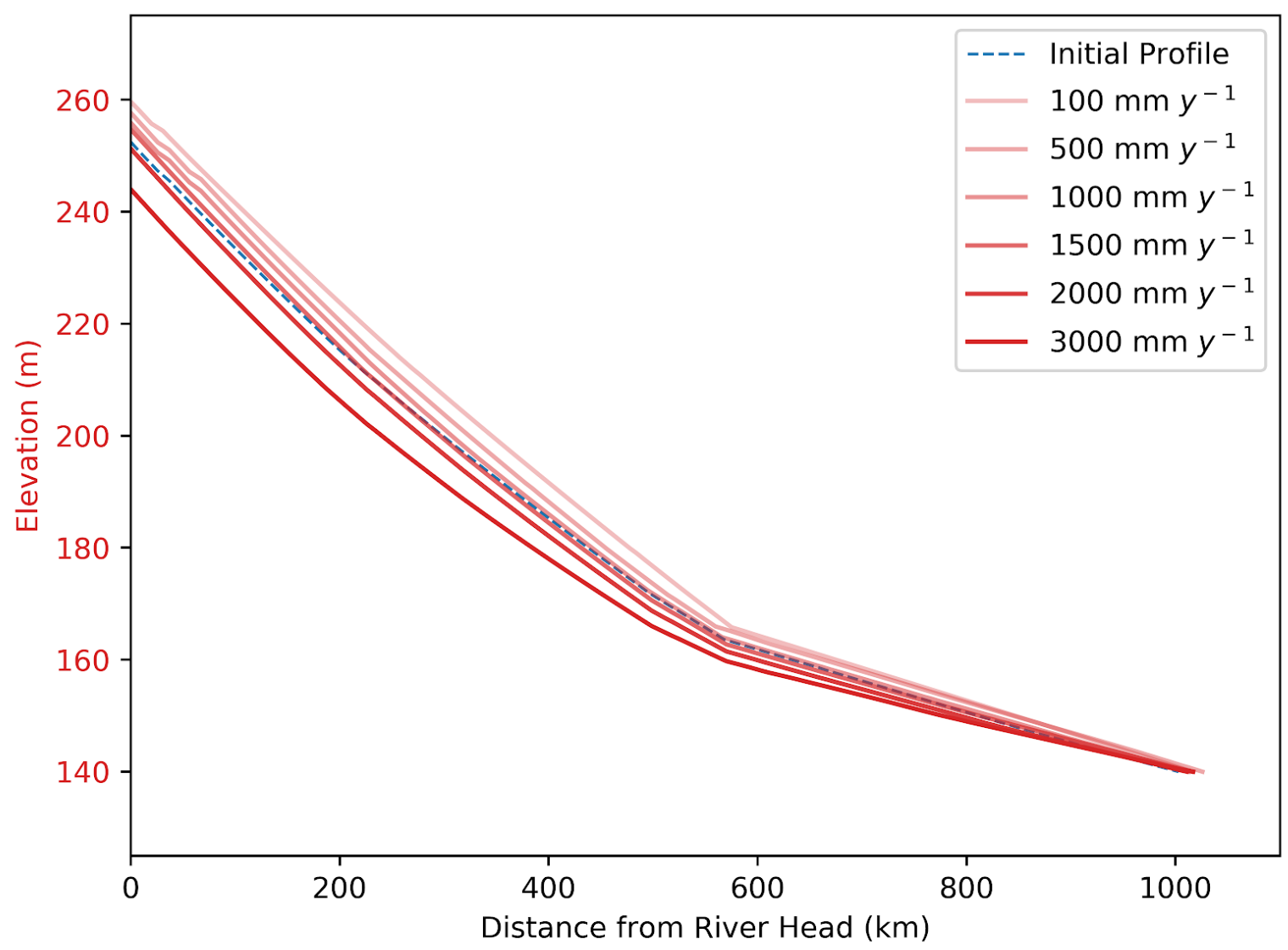

Flgure 5.9: Elevation profiles of the main tributary for different values of rainfall in the grid at $t$ $=10 \mathrm{ky}$. The values of rainfall tested are 100,500, 1000, 1500, 2000 and $3000 \mathrm{~mm} \mathrm{yr}^{-1}$. The initial profile of the tested scenarios is shown in blue dashed line. The resulting profiles show that when the rainfall increases the erosion takes place in all the profile, and when the rainfall decreases deposition takes place.

The comparison of the resulting topography with rainfall of 100 and $3000 \mathrm{~mm}$ $\mathrm{y}^{-1}$ shows that smaller tributaries also incise with the increase in rainfall (Figure 5.10). Even with the increase in the sediment volume supplied by the tributaries in a scenario with high rainfall rate, the trunk rivers also incise. This process is a consequence of the coefficient $m$ in equation 4.1 , defined as $m=1.54$, that performs a power relation with the carrying capacity $\left(Q_{\text {eqb }}\right)$ when the discharge increases. It is important to note that, differently from the incision and deposition due to base level change, which propagate upstream from the coast (e.g. Quirk, 1996), the modeled effects of varying rainfall act simultaneously in the whole model. 


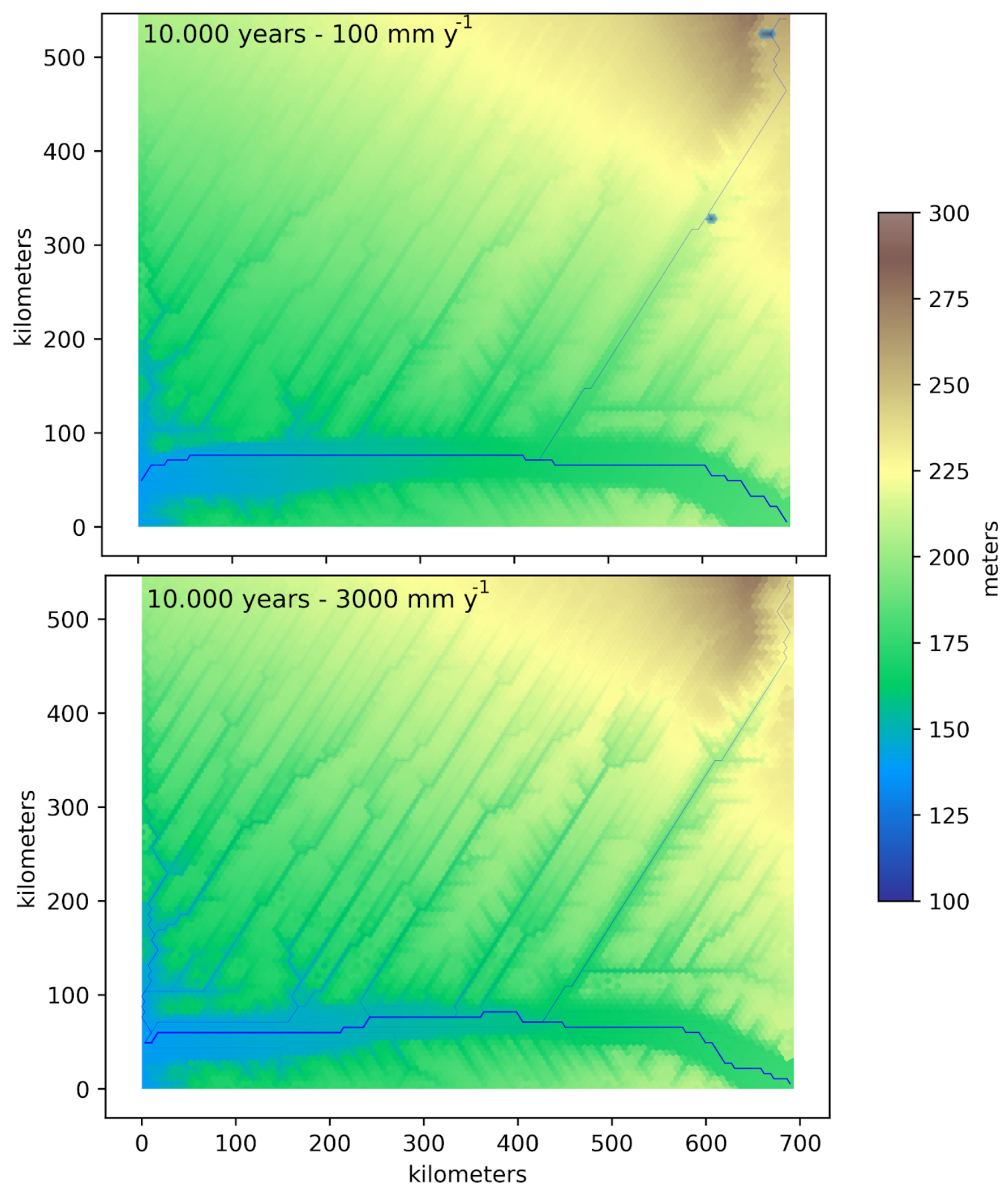

Figure 5.10: Comparison of the resulting topography of scenarios with rainfall of 100 and $3000 \mathrm{~mm} \mathrm{y}^{-1}$ at $\mathrm{t}=10 \mathrm{ky}$. The result with rainfall of $3000 \mathrm{~mm} \mathrm{yr}^{-1}$ shows that the smaller tributaries perform more incision with rainfall increase. An interesting aspect in the result with rainfall of $100 \mathrm{~mm}$ $\mathrm{yr}^{-1}$ is the formation of a small river valley lake (fluvial ria) next to the head of the main tributary, due the deposition caused by the decrease of rainfall. 


\subsection{Response of base level rise}

Section 5.2 discussed how incision due to base level drop occurs for different lateral erosion coefficients, and it was concluded that the most representative scenario for the region was for $L_{l e}=10^{3} \mathrm{~m}$. The objective of this section is to evaluate the numerical model response to a scenario with a base level rise, starting with a post-incision topography. For the study of the effects of the base level rise, the initial topography was the output topography of the scenario with $L_{l e}=10^{3}$ for $\mathrm{t}=10 \mathrm{ky}$ (Figure 5.6), with the same initial parameters used in Section 5.2. To increase the base level, the height of the model sink cells were raised at $10 \mathrm{~m} \mathrm{ka}^{-1}$ until $\mathrm{t}=5 \mathrm{ky}$ and later maintained at a constant height until $t=10 \mathrm{ky}$. The resulting evolution of topography is shown in Figure 5.11 and the evolution of elevation profile of the main tributary is shown in Figure 5.12.

During the initial stage of base level rise $(t=0,500$ and 2000 years in Figure 5.11) the elevation of the floodplain and channel increases with the base level, without marine incursion or the formation of lakes next to the sink cells. This occurs due to the sediments that are deposited in the cells with lower slope. With the rising of the base level, the slope next to the sink cells decreases, as shown in the elevation profiles (Figure 5.12). By the continuous decrease in the slope, the carrying capacity $\left(Q_{e q b}\right)$ also decreases and the trunk river loses its capacity of transport forming the lake next to sink cells (Figure 5.11 at $t=5 \mathrm{ky}$ ). After the base level rise stops, this lake is quickly infilled (Figure 5.11 at $t=7 \mathrm{ky}$ ). Even after the end of base level rise, at $\mathrm{t}=5 \mathrm{ka}$, the elevation profiles show an increase in the elevation of the trunk river and its main tributary (Figure 5.12). If the total time of the model was longer than $10 \mathrm{ka}$, this deposition condition would persist until the profiles reached a new equilibrium state.

The formation and the infill of river valley lakes, or fluvial rias (e.g. Irion \& Kalliola, 2010), are also reproduced by the model on the small tributaries of the trunk river (Figure 5.11 at $\mathrm{t}=5,7$ and $10 \mathrm{ky}$ ). This process occurs because small incised tributaries do not have the sediment flux necessary for a fast infill of the formed lakes by the elevation of the floodplain of the trunk river. However, with time these formed fluvial rias are infilled at last. 

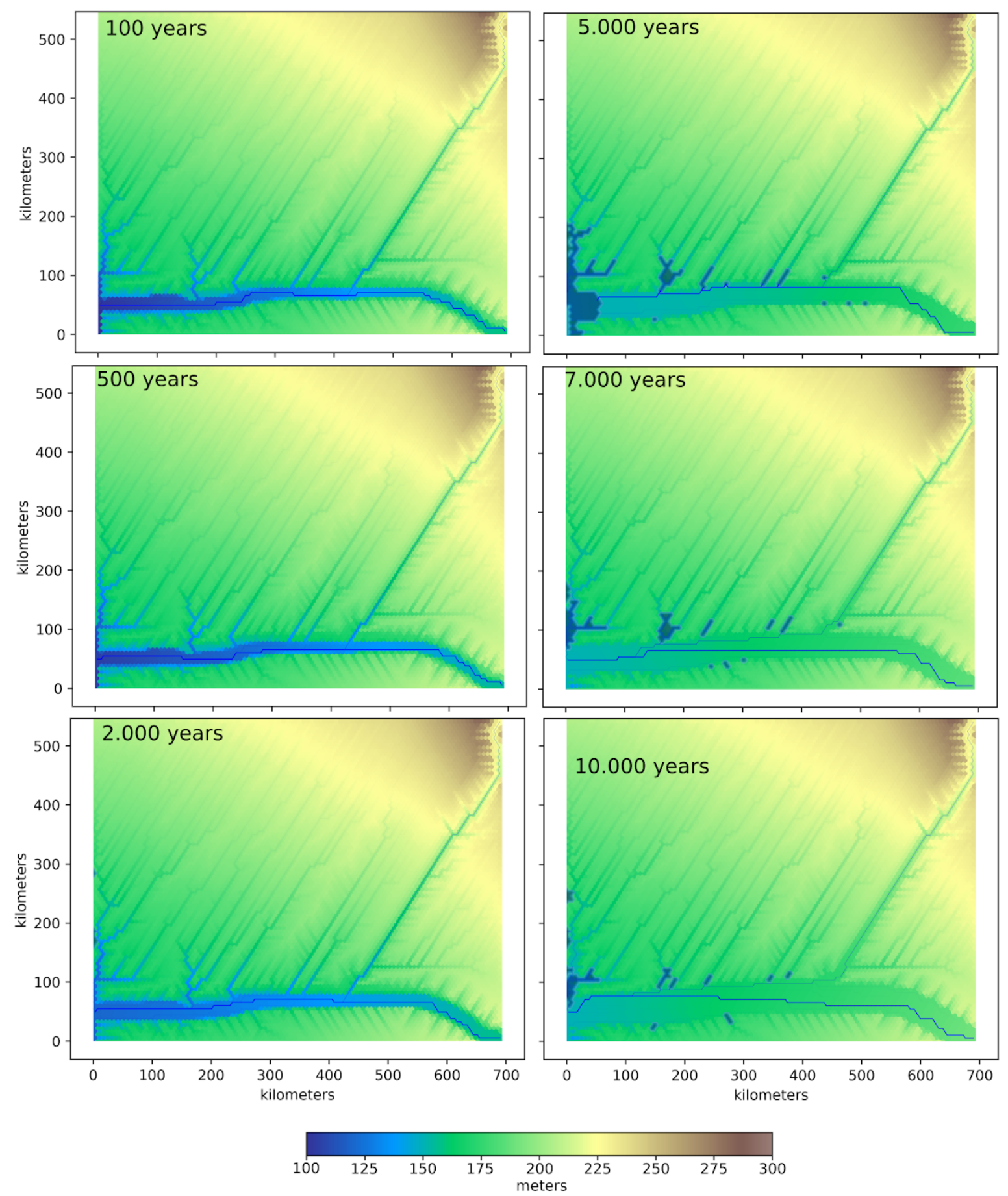

Figure 5.11: Response of the topography in the model to a base level rise. The sink cells (lower left corner) start with 100 meters of elevation and rise at a rate of $10 \mathrm{~m} \mathrm{ka}^{-1}$ until $\mathrm{t}=5 \mathrm{ka}$, after that they maintain their height constant until $t=10 \mathrm{ky}$. Formed lakes in figures with $\mathrm{t}=5,7$ and $10 \mathrm{ky}$ are shown as connected smooth blue hexagons. The lakes formed on the lower end of tributaries of the trunk river are known as fluvial rias. 
Another important detail in the result is the increase in the width of the floodplain in the trunk river during and after the base level rise (Figure 5.11). The depositional conditions of the rivers in this scenario, seen in the elevation profiles in Figure 5.12, cause an increase in the avulsion rates which on their turn increase the chance of the channel being on the edge of the valley and laterally eroding it. The width of the valley in the main tributary increases next to the confluence with the trunk river (Figure 5.11 at $\mathrm{t}=10 \mathrm{ky}$ ), what is expected, since, in the elevation profiles (Figure 5.12), the most upstream region of main tributary had small changes in its elevation during the modeled time of $10 \mathrm{ky}$.

The work of Constantine (2014) discusses the increase of lateral migration in channels when the sedimentary flux increases, causing deposition. However, by the result shown in this section, the slope is another important factor that can control deposition and consequently the increase in lateral migration of a channel.

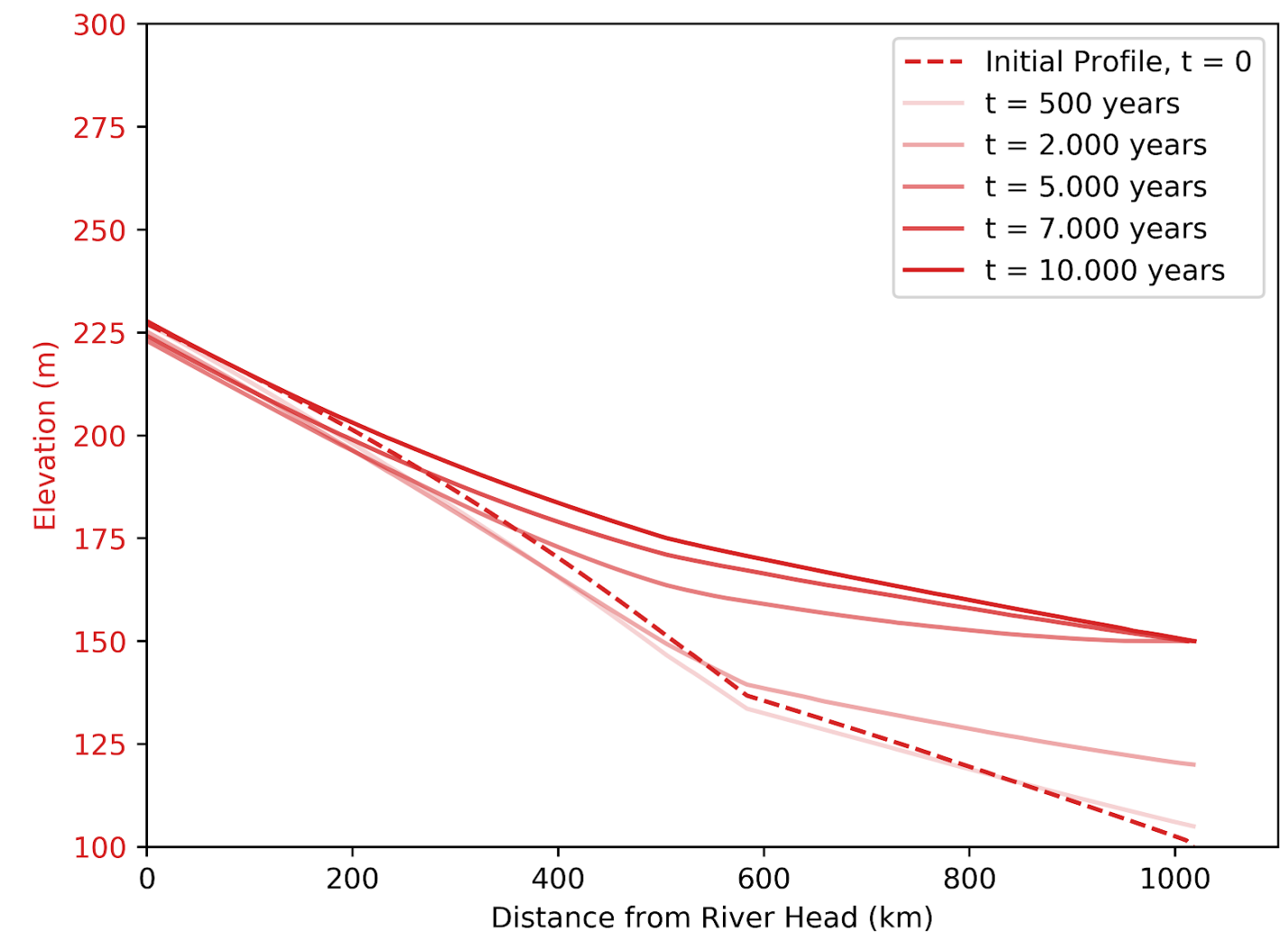

Figure 5.12: Evolution of the elevation profile of the main tributary in a scenario with base level rise. The profile had small changes next to the river head, showing even a remaining incision until $\mathrm{t}=500$ years. The response to the base level rise is an increase in elevation of the profile, with variation increasing downstream of the river, even after the base level stop at $\mathrm{t}=5 \mathrm{ky}$. 


\subsection{Topography due to tectonism}

Neotectonics has been argued to be a first order control on river patterns and orientation (e.g. Igreja, 2012), development of ria lakes (e.g. Rossetti et al., 2014) and distribution of altitudes, orientation and width of in-valley alluvial plains (e.g. Latrubesse \& Franzinelli, 2002, Rossetti et al. 2014, Passos et al. 2020) in Amazonia. Nevertheless, no evaluation of the quantitative aspects of these models in terms of tectonic-Earth surface processes interactions has been considered, as the models are based on indirect evidence of fault activity. To evaluate the response of topography and drainage to the hypothetical tectonism, a scenario was created with two defined areas of subsidence: one in the floodplain of the trunk river and the other on an elevated terrace. To simulate the formation of grabens in the numerical model, a subsidence rate of $0.5 \mathrm{~m} \mathrm{ka}^{-1}$ is applied in both regions, starting with the initial topography (the cells inside the rectangles shown in Figure 5.13, at $t=0$ years). The subsidence rate is equal to what is found in active rifts in the major extensional provinces on Earth (e.g. Xie and Heller, 2009), therefore representing an extreme scenario.

The resulting topography at $t=30$ ky does not show any perturbation on the surface of the subsiding area inside the floodplain of the trunk river (Figure 5.13). That is due to the rate of sedimentary infill being much greater than the subsidence rate. Additionally, the graben margin faults are not coincident with the valley margins (as interpreted in many previous works, e.g. Latrubesse \& Franzinelli, 2002, Rossetti et al. 2014, Passos et al. 2020), and are not visible at all, as the incipient escarpments are constantly being eroded and covered by the intense alluvial dynamics.

On the other hand, the subsiding area on the terrace preserved the exact form of the graben, which subsided 15 meters in 30 ky (Figure 5.13). The preservation of this graben is due to the low carrying capacity of small rivers that flow in the cells of this region. The presence of terraces higher than these rivers hamper the input of sediments from the larger rivers, enabling the preservation of tectonically lowered terrace surfaces. This result raises a question about the hypothesis of neotectonics and the existence of grabens in the Solimões River floodplain. Why are 
the interpreted grabens only recognized in the floodplains (e.g. Latrubesse \& Franzinelli, 2002, Rossetti et al. 2014, Passos et al. 2020)?

In fact, our assessment of the quantitative interplay between tectonics and Earth-surface processes reveals three main flaws in the neotectonic hypothesis:

1- Rivers are not captured by isolated grabens, since the elevated graben shoulders prevent avulsion in that direction. That is clear in figure 5.13, where the graben was placed just a couple cells apart from the river and no capture of the river water or sediments took place.

2- Valley margins are very dynamic erosional features that do not represent fault escarpments, even though roughly straight reaches are very common as a consequence of the main control on river direction, which is the local slope. The lower picture in Figure 5.13 clearly shows that the valley is wider than the graben, and in that case the orientation coincidence is due to the arbitrary placement of the graben long axis in the same direction of river flow.

3- Grabens developed on the huge interfluve areas out of the main river valleys would be the ones most clearly recognizable from airborn or orbital images and elevation models. Since these have not been interpreted in the literature and there is no reason for the grabens to coincide with river valleys (see point 1 ), the interpretation of the supposed lineaments and erosional escarpments bounding river valleys and rias as tectonic features is most likely wrong. 


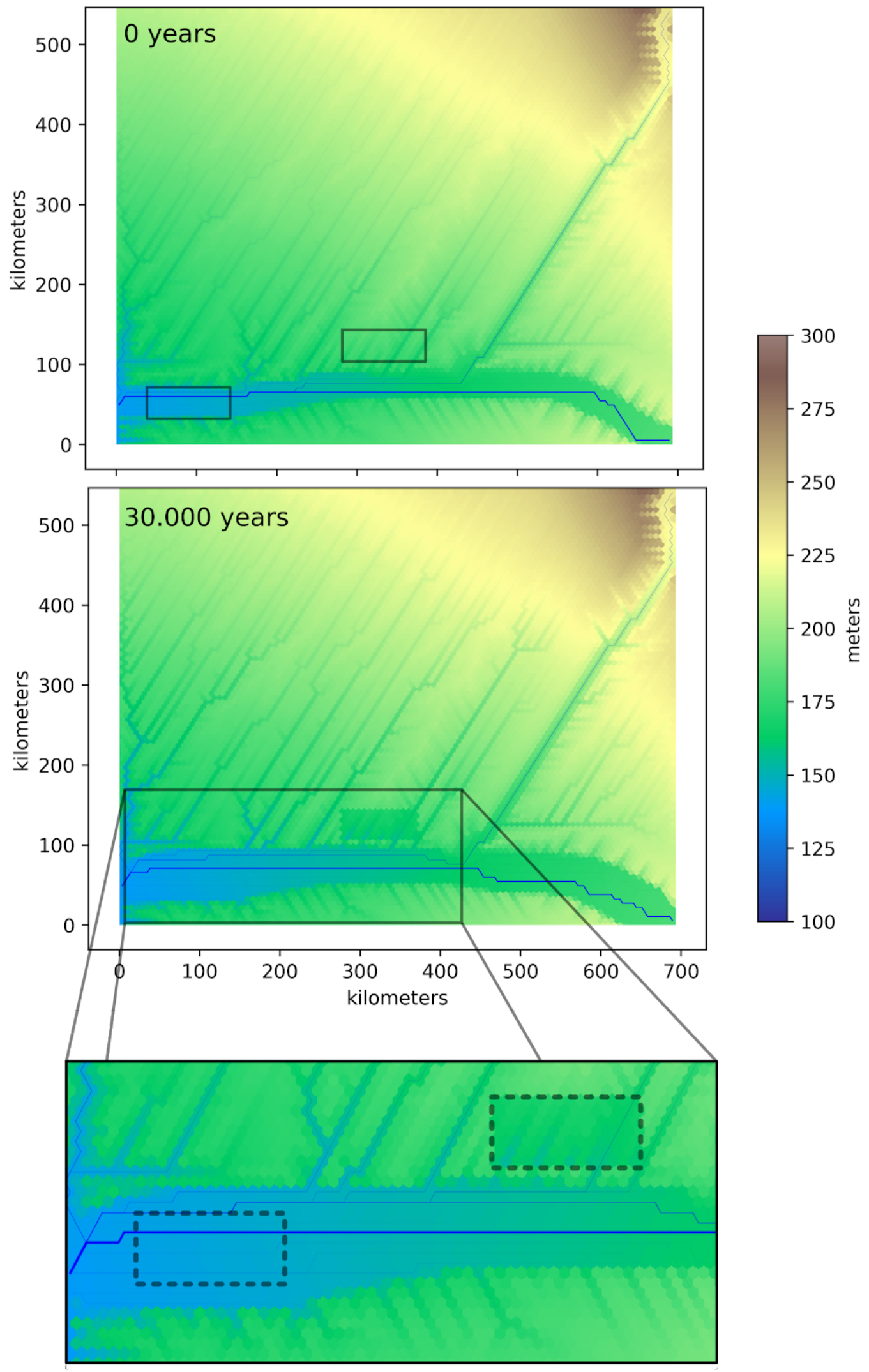

Figure 5.13: Topographic and drainage response due to tectonism. The initial topography at $t$ $=0$ years shows the regions where, in the cells inside the rectangles, a subsidence of $0.5 \mathrm{~m} \mathrm{ka}^{-1}$ occurs for $30 \mathrm{ky}$. 


\subsection{Effects of change in the position of the trunk river}

This section evaluates how the topography and the elevation profile of the main tributary responds to a change of position in the confluence with the trunk river, caused by a hypothetical upstream avulsion of the trunk river, outside the grid of the model. To create this situation, in the same initial topography of Section 5.1, the trunk river has its input cell of discharge and sediment changed to a position next to the input cell of the main tributary (Figure 5.15 at $t=0$ years). The initial parameters used are the same of Section 5.2.

The resulting augmented discharge in the reach downstream of the new confluence triggered an incision where the main tributary once flowed, and a volume of sediment was relocated to the old floodplain of the trunk river, forming a fluvial ria (Figure 5.14 and Figure 5.15 at $\mathrm{t}=2 \mathrm{ky}$ ). And at $\mathrm{t}=10 \mathrm{ky}$ the new valley of the trunk river is developed and the main tributary is incised to the new base level (Figure 5.14 and Figure 5.15 at $t=10 \mathrm{ky}$ ). These processes mimic the effects of base level fall or climate change. They are triggered by the autogenic control of river avulsion and might be mistaken for an allogenic-controlled feature, (see items 5.2 and 5.4.).

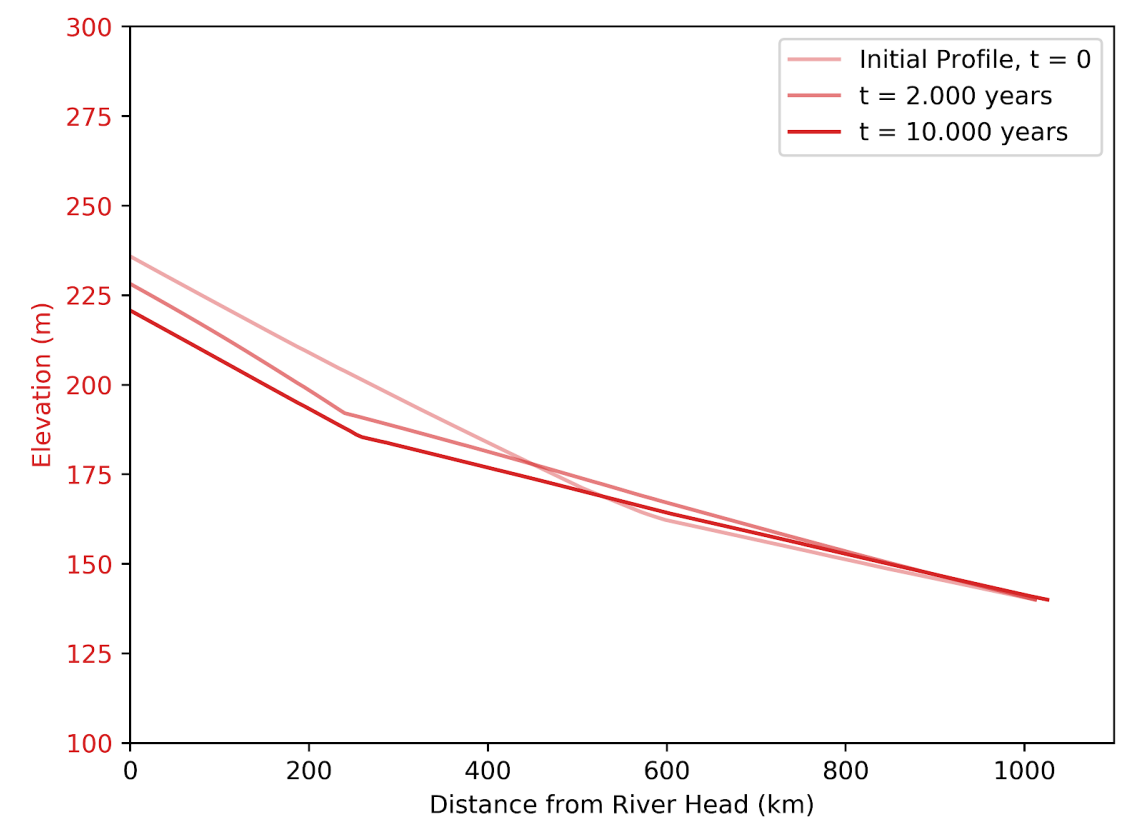

Figure 5.14: Evolution of elevation profile of the main tributary with an initial scenario where the trunk river is inputted in a cell next to the input of the main tributary. This result shows an incision at the head of the main tributary. 


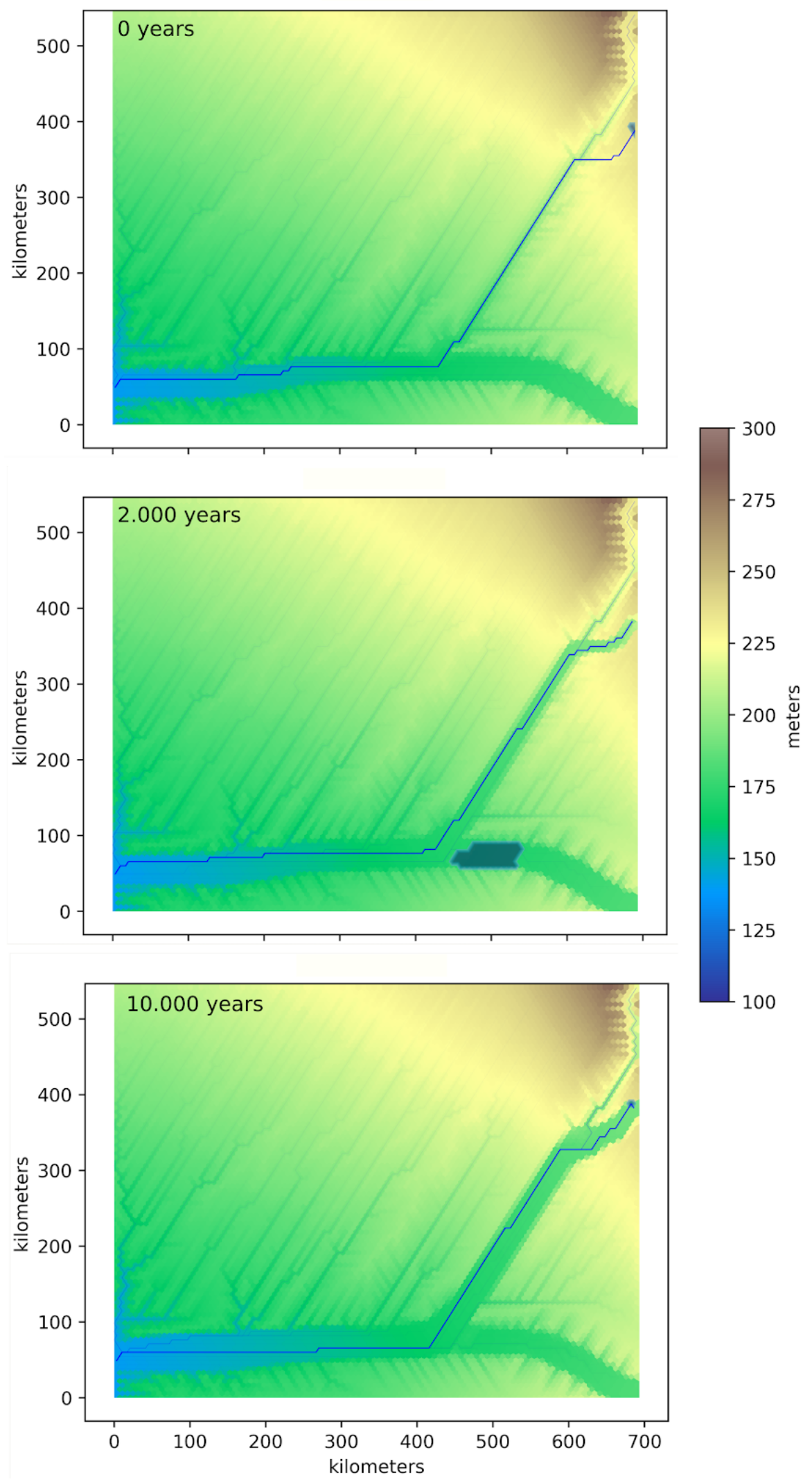

Figure 5.15: Evolution of topography with an initial scenario where the trunk river is inputted in a cell next to the input of the main tributary. A fluvial ria is formed, at $t=2 \mathrm{ka}$, in the old Solimões River floodplain due to the volume of sediment relocated. 


\section{CONCLUSIONS}

This dissertation presents a new numerical model (SPASE) that simulates the evolution of alluvial landscapes at the scale of $10^{5} \mathrm{~km}^{2}$, being capable of reproducing the formation of floodplains and terraces in conditions similar to Central Amazonia during the Quaternary. In order to reproduce the formation of floodplains, this model introduces a simplified approach that reproduces not only channel bed erosion but also lateral bank erosion. To test basic concept models, the model was applied to different conditions of lateral erodibility, sedimentary input from external rivers, rainfall, base level change, tectonism and position of mainstem rivers controlling local base level.

Model runs presented in Section 5.2 reveal that the lateral bank erosion is an important process controlling floodplain development, particularly incision in case of base level drop. High lateral erosion rates imply faster and greater widening of valleys, and, in the case of base level drop, limits the upstream propagation of incision. On the other hand, low lateral erosion rates delay the widening of the floodplain but increases the propagation of incision upstream. These results show the importance of modeling lateral bank erosion with realistic rates to study the development of floodplains and terraces in alluvial landscapes. It is advisable that future landscape evolution models concerned with alluvial environment morphology, erosion rates at low-slope areas and regional-scale sediment fluxes should incorporate the simulation of such processes.

Results from the model in Section 5.3 show that the relation between sediment and water discharge input from the model grid boundary has a great influence on the river profile slope. The greater the amount of sediment in relation to water discharge the greater is the slope.

Incisional and agradational scenarios in the river valleys were obtained with three different model settings:

1- Variations in rainfall (Section 5.4) show that climate change can induce an incisive scenario, when the rainfall rates increase, or a depositional scenario, when the rainfall rates decrease. The process can lead to several meters of incision or 
deposition as a consequence of rainfall variation within an order of magnitude and operates simultaneously at the whole river profile.

2- Base level variation (Sections 5.2. and 5.5) causes upstream propagation of incision or aggradation. The results show that base level rise, in a previously incised initial scenario, induces the deposition of sediments in the floodplain of the main river and the formation of fluvial rias in the small tributaries. Another consequence of the base level rise is the widening of the floodplains due to the increased rate of avulsion of the rivers during aggradation. It is also important to note that, during base level fall, the upstream propagation of incision is dependent on the sediment flux and water discharge, which limit can give rise to a depositional wedge in upstream reaches even during base level drop. This process is greatly amplified by lateral bank erosion (Section 5.2.).

3- Changes in the position of the confluence between two rivers, with different discharges (Section 5.7), induces a local base level drop in the smaller river and consequently an upstream incision, changing its elevation profile.

Given the ambiguity in interpreting the external controls to incision and deposition in similar environments, the three processes should be considered before a direct interpretation of either eustastic or climate change processes is proposed.

The quantitative interplay between tectonics and Earth-surface processes was tested by defining graben-sized areas undergoing subsidence during the model run, one in the trunk river valley and another on a nearby terrace. The main conclusions of that model setting contradict previous assumptions on the role of neotectonic in controlling river valleys and rias in Amazonia:

1- Rivers are not captured by isolated grabens, since the elevated graben shoulders prevent avulsion in that direction.

2- Valley margins are not conditioned or influenced by graben margins, being very dynamic erosional features that do not maintain their position, but migrate outwards, even where a subsiding area is placed in the alluvial plain. Straight escarpments are very common even without the incorporation of tectonics to the model, following local slopes.

3- Grabens developed on the huge interfluve areas out of the main river valleys would be the ones most clearly recognizable from airborn or orbital images 
and elevation models, as they would be less affected by erosional or depositional processes. These have not been described in the literature and there is no reason for the grabens to coincide with river valleys (see point 1 ), bringing additional problems for the neotectonic model.

Based on the model results, it is not necessary to evoque tectonic activity to explain the observed features in the alluvial environments of central Amazonia.

The construction of a new numerical model aimed at evaluating the quantitative relevance of different parameters controlling water discharge, sediment flux, deposition and erosion in central Amazonia opens the possibility to test hypotheses, conceptual models and scenarios concerning the evolution of valleys and terrace systems during the Quaternary in Amazonia. 


\section{REFERENCES}

Anhert, F., 1976, Brief description of a comprehensive three-dimensional process-response model of landform development: Zeitschrift für Geomorphologie, v. 25, p. 29-49.

Beaumont, C., Fullsack, P. Hamilton, J., 1992, Erosional control of active compressional orogens, in McClay, K.R. , ed., Thrust Tectonics: London, Springer-Science+Business Media, B.V., p. 1-18., doi:10.1007/978-94-011-3066-0.

Bicudo, T.C., Sacek, V., Almeida, R.P., Bates, J.M., Ribas, C.C., 2019, Andean Tectonics and Mantle Dynamics as a Pervasive Influence on Amazonian Ecosystem: Scientific Reports, v. 9, 16879, doi: 10.1038/s41598-019-53465-y.

Braun, J., Sambridge, M., 1997, Modelling landscape evolution on geological time scales: a new method based on irregular spatial discretization: Basin Research, v. 9, p. 27-52, doi: 10.1046/j.1365-2117.1997.00030.x.

Braun, J., 2006, Recent advances and current problems in modelling surface processes and their interaction with crustal deformation: Geological Society of London Special Publications, v. 253, p. 307-325, doi: 10.1144/GSL.SP.2006.253.01.16.

Constantine, J.A., Dunne, T., Ahmed, J., Legleiter, C., Lazarus, E.D., 2014, Sediment supply as a driver of river meandering and floodplain evolution in the Amazon Basin: Nature Geoscience, v. 7, p. 899-903, doi: 10.1038/ngeo2282.

Coulthard, T.J., Kirkby, M.J., Macklin, M.G., 1999, Modelling the impacts of Holocene environmental change on the fluvial and hillslope morphology of an upland landscape, using a cellular automaton approach, in Brown A.G., Quine T.M., eds., Fluvial Processes and Environmental Change: New York, Wiley, p. 31-47.

Coulthard, T.J., 2001, Landscape evolution models: a software review: Hydrological Processes, v. 15, p. 165-173, doi: 10.1002/hyp.426.

Davis, W.M., 1902, Baselevel, grade and peneplain: The Journal of Geology, v. 10, p. 77-111.

Filizola, N., Guyot, J.L., 2009, Suspended sediment yields in the Amazon basin: an assessment using the Brazilian national data set: Hydrological Processes, v. 23, p. 3207-3215. 
Guimberteau, M., Ronchail, J., Espinoza, J.C., Lengaigne, M., Sultan, B., Polcher, J., Drapeau, G., Guyot, J.L., Ducharne, A., Cialis, P., 2013, Future changes in precipitation and impacts on extreme streamflow over Amazonian sub-basins: Environmental Research Letters, v. 8, p. 1-13, doi: 10.1088/1748-9326/8/1/014035.

Hoorn, C. , et al., 2010, Amazonia Through Time: Andean uplift, climate change, landscape evolution, and biodiversity: Science, v. 330, p. 927-931, doi: 10.1126/science.1194585.

Howard, A.D., 1994, A detachment limited model of drainage basin evolution: Water Resources Research, v. 30, p.: 2261-2285, doi: 10.1029/94WR00757.

Igreja, H.L.S., 2012, A neotectônica e as mudanças hidrogeológicas do sistema fluvial Solimões Amazonas: "Encontro das Águas de Manaus - EAM - Amazonas, Brasil: Revista Geonorte, Edição Especial, v. 3, p. :20-33.

Irion, G., Kalliola, R., 2010, Long-term landscape development processes in Amazonia, in Hoorn, C., Wesselingh, F., eds., Amazonia: Landscape and Species Evolution: A Look into the Past: Oxford, Wiley-Blackwell, p. 185-197, doi: 10.1002/9781444306408.ch22.

Kirkby, M.J., 1987, Modelling some influences of soil erosion, land-slides and valley gradient on drainage density and hollow development: Catena Supplement, v. 10, p. 1-14.

Latrubesse, E.M., Franzinelli, E., 2002, The Holocene alluvial plain of the middle Amazon River, Brazil: Geomorphology, v. 44, p. 241 - 257, doi: 10.1016/S0169-555X(01)00177-5.

Latrubesse, E.M.; Stevaux, J. C.; Sinha, R., 2005, Tropical rivers: Geomorphology, v. 70, p.187-206, doi: 10.1016/j.geomorph.2005.02.005.

Nicholas, A.P., et al., 2012, Modelling hydrodynamics in the Rio Paraná, Argentina: an evaluation and inter-comparison of reduced-complexity and physics based models applied to a large sand-bedriver: Geomorphology, v. 169-170, p. 192-211, doi: 10.1016/j.geomorph.2012.05.014.

Passos, M.S., Soares, E.A.A., Tatumi, S.H., Yee, M., Mittani, J.C.R., Hayakawa, E.H., Salazar, C.A. 2020, Pleistocene-Holocene sedimentary deposits of the Solimões-Amazonas fluvial system, Western Amazonia: Journal of South American Earth Sciences, doi: 10.1016/j.jsames.2019.102455. 
Pupim, F.N., et al., 2019, Chronology of Terra Firme formation in Amazonian lowlands reveals a dynamic Quaternary landscape: Quaternary Science Reviews, v. 210, p. 154-163, doi: 10.1016/j.quascirev.2019.03.008.

Quirk, D.G., 1996, Base profile: a unifying concept in alluvial sequence stratigraphy, in Aitken, J.F., Howell, J., eds., High Resolution Sequence Stratigraphy: Innovations and Applications: London, Geological Society Special Publication, v. 104, p. 37-49, doi: 10.1144/GSL.SP.1996.104.01.01.

Ribas, C.C., Aleixo, A., Nogueira, A.C.R., Miyaki, C.Y., Cracraft, J, 2012, A palaeobiogeographic model for biotic diversification within Amazonia over the past three million years: Proceedings of the Royal Society B: Biological Sciences, v. 279, p. 681-689, doi: 10.1098/rspb.2011.1120.

Ribas, C.C., Aleixo, A., 2019, Diversity and evolution of Amazonian birds: implications for conservation and biogeography: Anais da Academia Brasileira de Ciências, v. 91, supl. 3, p. 1-9, doi: 10.1590/0001-3765201920190218.

Rossetti, D.F., 2014, The role of tectonics in the late Quaternary evolution of Brazil's Amazonian landscape: Earth-Science Reviews, v. 139, p. 362-389, doi: 10.1016/j.earscirev.2014.08.009.

Rossetti, D. F., Toledo, P. M., Góes, A. M., 2005, New geological framework for Western Amazonia (Brazil) and implications for biogeography and evolution: Quaternary Research, v. 63, p. 78-89, doi: 10.1016/j.yqres.2004.10.001.

Sacek, V., 2011, Modelagem numérica conjunta de processos sedimentares e tectônicos em bacias sedimentares. [Tese de Doutorado]: São Paulo, Universidade de São Paulo, Instituto de Astronomia, Geofísica e Ciências Atmosféricas, doi: 10.11606/T.14.2011.tde-21062013-151844.

Sacek, V., 2014, Drainage reversal of the amazon river due to the coupling of surface and lithospheric processes: Earth and Planetary Science Letters, v. 401, Supplement C, p. 301- 312, doi: 10.1016/j.epsl.2014.06.022.

Shanley, K.W., McCabe, P.J., 1993, Alluvial architecture in a sequence stratigraphic framework: a case history from the Upper Cretaceous of Southern Utah, U.S.A., in Bryant, I.D., Flint, S.S., eds., 
The Geological Modelling of Hydrocarbon Reservoirs and Outcrop Analogues: Oxford, Boston, Blackwell Scientific Publications, International Association of Sedimentologists Special Publication, v. 15, p. 21-55, doi 10.1002/9781444303957.ch2.

Sioli, H., 1984, The Amazon and its main afluents: hydrography, morphology of the river courses, and river types, in Sioli, H., ed., The Amazon: Dordrecht, Springer, p. 127-165.

Tucker, G.E., Slingerland, R.L., 1994, Erosional dynamics, flexural isostasy, and long-lived escarpments: a numerical modelling study: Journal of Geophysical Research, v. 99, p. 229-243, doi: 10.1029/94JB00320.

Tucker, G.E., Lancaster, S.T., Gasparini, N.M., Bras, R.L., Rybarczyk, S.M., 2000, An object-oriented framework for hydrologic and geomorphic modeling using triangulated irregular networks: Computers and Geosciences, v. 27, p. 959-973, doi: 10.1016/S0098-3004(00)00134-5.

Van De Wiel, M.J., Coulthard, T.J., Macklin, M.G., Lewin, J., 2007, Embedding reach-scale fluvial dynamics within the CAESAR cellular automaton landscape evolution model: Geomorphology, v. 90, p. 283-301, doi: 10.1016/j.geomorph.2006.10.024.

Whipple, K., Tucker, G., 2002, Implications of sediment-flux-dependent river incision models for landscape evolution: Journal of Geophysical Research, v. 107, p. 1-20, doi: 10.1029/2000JB000044.

Wilkinson, M.J., Marshall, L.G., Lundberg, J.G., Kreslavsky, M.H., 2010, Megafan environments in northern South America and their impact on Amazon Neogene aquatic ecosystems, in Hoorn, C., Wesselingh, F.P., eds., Amazonia Landscape and Species Evolution: A Look into the Past: Oxford, Blackewell, p. 162-184, doi: 10.1002/9781444306408.ch22.

Xie, X., Heller, P.L., 2009, Plate tectonics and basin subsidence history: Geological Society of America Bulletin, v. 121, p. 55-64, doi: 10.1130/B26398.1. 